NBER WORKING PAPER SERIES

\title{
INCREASING COMMUNITY COLLEGE COMPLETION RATES AMONG LOW-INCOME STUDENTS: \\ EVIDENCE FROM A RANDOMIZED CONTROLLED TRIAL EVALUATION \\ OF A CASE MANAGEMENT INTERVENTION
}

William N. Evans

Melissa S. Kearney

Brendan C. Perry

James X. Sullivan

Working Paper 24150

http://www.nber.org/papers/w24150

\author{
NATIONAL BUREAU OF ECONOMIC RESEARCH \\ 1050 Massachusetts Avenue \\ Cambridge, MA 02138 \\ December 2017
}

We are indebted to Erin Byrne and Luke Horvath for their project and research support and we gratefully acknowledge the research assistance of Sreeraahul Kancherla, Fernando Saltiel, and Tim Seida. The paper has benefitted from comments from Susan Dynarski, Josh Goodman, Jonathon Guryan, Judy Hellerstein, Brad Hershbein, Isaac McFarlin, Lesley Turner, Marci Ybarra, and seminar participants at the University of Wisconsin, IRP Summer Workshop, University of Notre Dame, the NBER's Education Program, the IFS/CEP Joint Conference : Wages, Labour Market Policy and the Safety Net, the DC Economics of Education working group, and at the APPAM Fall Research Conference. We are grateful to our research partners at Catholic Charities Fort Worth and Tarrant County College. This study was registered in the American Economic Association's RCT Registry under ID AEARCTR-0000223. This research was financially supported by funding from the Wilson Sheehan Lab for Economic Opportunities at Notre Dame, the Fischer Family Foundation, the Abdul Latif Jameel Poverty Action Lab, and NIH Grant \#1R21HD081399-01A1. The views expressed herein are those of the authors and do not necessarily reflect the views of the National Bureau of Economic Research.

NBER working papers are circulated for discussion and comment purposes. They have not been peer-reviewed or been subject to the review by the NBER Board of Directors that accompanies official NBER publications.

(C) 2017 by William N. Evans, Melissa S. Kearney, Brendan C. Perry, and James X. Sullivan. All rights reserved. Short sections of text, not to exceed two paragraphs, may be quoted without explicit permission provided that full credit, including $\odot$ notice, is given to the source. 
Increasing Community College Completion Rates among Low-Income Students: Evidence from a Randomized Controlled Trial Evaluation of a Case Management Intervention William N. Evans, Melissa S. Kearney, Brendan C. Perry, and James X. Sullivan NBER Working Paper No. 24150

December 2017

JEL No. I23,I3

\begin{abstract}
Community colleges are an important part of the higher education landscape in the United States, but completion rates are extremely low, especially among low-income students. Much of the existing policy and research attention to this issue has focused on addressing academic and financial challenges. However, there is ample reason to think that non-academic obstacles might be key drivers of dropout rates for students living with the burden of poverty. This study examines the impact of a comprehensive case management intervention that is designed specifically to help low-income students overcome the multitude of barriers to college completion. We evaluate the impact of this intervention through a randomized controlled trial evaluation (RCT) conducted between 2013 and 2016 in Fort Worth, Texas. Eligible students were randomly assigned to a treatment group that was offered comprehensive case management, including emergency financial assistance (EFA), a separate treatment group offered only EFA, or a control group. Data from school administrative records indicate that the comprehensive case management program significantly increases persistence and degree completion, especially for women. Estimates for the full sample are imprecise, but the estimates for women imply that the case management intervention tripled associate degree receipt (31 percentage point increase).We find no difference in outcomes between the EFA-only treatment arm and the control group. A back-of-the-envelope calculation using average earnings gains associated with community college completion implies that program benefits exceed program costs $(\$ 5,640$ per student for three year program) after only 4.25 years in the workforce post schooling.

William N. Evans

Keough-Hesburgh Professor of Economics

Department of Economics

University of Notre Dame

3111 Jenkins Nanovic Halls

Notre Dame, IN 46556-7000

and NBER

wevans1@nd.edu

Melissa S. Kearney

Department of Economics

University of Maryland

3105 Tydings Hall

College Park, MD 20742

and NBER

kearney@econ.umd.edu

Brendan C. Perry

Wilson Sheehan Lab for Economic Opportunities 3104 Jenkins Nanovic Halls

University of Notre Dame

Notre Dame, IN 45630

bperry3@nd.edu

James X. Sullivan

Department of Economics

3108 Jenkins Nanovic Halls

University of Notre Dame

Notre Dame, IN 46556

James.X.Sullivan.197@nd.edu
\end{abstract}




\section{INTRODUCTION}

Community college is a crucial component of the United States' education system, offering millions of students the opportunity to earn a low-cost, two-year associate's degree, gain career and technical credentials, or embark on a path to a four-year institution. Low tuition rates and open-access policies at community colleges make them accessible to students who might face significant barriers to attending four-year selective schools. Federal grants and loans mean that many low-income students are paying little if any out-of-pocket for a community college education. ${ }^{1}$ Nearly half of all undergraduate students in the U.S. in 2014-15 were enrolled in a two-year institution (U.S. Department of Education, 2016) and half of all bachelor's recipients were at one point enrolled at a community college before transferring to a four-year institution (National Student Clearinghouse (NSC) Research Center, 2017). Many studies find employment and earnings benefits associated with community college degree completion and credits earned (e.g., Kane and Rouse, 1995; Marcotte et al., 2005; Jepsen et al., 2014; Stevens et al., 2015). A recent estimate suggests that for the cohort of students who attended college in the mid-2000s, an associate's degree yields an earnings premium of about 30 percent over a high school degree (Marcotte, 2016).

Despite low tuition costs and the expected economic returns, a large fraction of community college students drop out before earning a credential or degree. The National Student Clearinghouse (2017) notes that among students who first enrolled full-time at a two-year public institution in 2010, nearly 42 percent had not received any degree or were no longer enrolled in school six-years later. Many observers argue that there is a "completion crisis" at all type of colleges. The NSC estimates that of students that started at four-year public and private institutions in 2010, only 59 and 72 percent have bachelor's degrees after six years. The President of Arizona State University recently noted that “...the

\footnotetext{
${ }^{1}$ Data from the 2011/12 National Postsecondary Student Aid Study indicates that 38 percent of community college students have zero out of pocket expenses for tuition and fees.

https://www.usnews.com/news/articles/2015/02/17/how-many-already-attend-community-college-for-free
} 
discussion of a debt crisis often fails to address what I would argue is the greater crisis: the fact that more than half of those who start college fail to finish."’2 Likewise, Deming (2017) argues that the key policy issue is college completion rather than college attendance. Not completing can be financially crippling for a community college student as they incur debt but do not obtain a degree. Although only 40 percent of community college students acquire education-related debt, ${ }^{3} 90$ percent of community college students who have defaulted on debt left college with no degree or certificate. ${ }^{4}$

The completion crisis is occurring at a time when a greater share of students are going to college. ${ }^{5}$ The high dropout numbers might be driven in part by the fact that less prepared, lower income students are now more likely to attend college, and these students tend to drop out at much higher rates (Baum and Scott-Clayton, 2013). A likely culprit, especially for low-income community college students, is that many of these students face a wide range of challenges, beyond academic preparation issues, that they are not necessarily able to overcome. Given that community college students tend to be financially independent and older, financial and family issues frequently arise and pose challenges to staying in school. ${ }^{6}$ These problems include balancing work and school, finding appropriate and affordable day care, and dealing with shocks that occur during the school year. In addition, many students report having trouble navigating the complex community college system, particularly first generation college students and new immigrants who may have limited knowledge about how colleges function (Bailey, Jenkins, and Leinbach, 2005; Scott-Clayton, 2011). Students might also lack the necessary commitment and/or planning and time management skills necessary to set out a

\footnotetext{
2 https://president.asu.edu/node/2241

${ }^{3}$ https://trends.collegeboard.org/sites/default/ files/trends-in-community-colleges-research-brief.pdf

${ }^{4}$ https://www.insidehighered.com/news/2015/09/28/four-surprising-findings-debt-and-default-among-communitycollege-students

${ }^{5}$ Using data from the 1 Percent Census PUMS from 1980 through 2000 and the 2010 and 2015 American Communities Survey, the fraction of those aged 25-29 who have ever attended college or is currently attending college is the following (year, percent); 1980, 50.1 percent; 1990, 55.1 percent; 2000, 60.3 percent; 2010, 64.3 percent; 2015, 67.3 percent. ${ }^{6}$ Survey evidence from Johnson et al. (2011) suggests that the leading self-reported reason why students drop out of college is a need to work full time (71 percent). Another common reason reported was not having enough time to spend with family (41 percent.) The reason that ranked the lowest was "some classes were too difficult" (10 percent reported this as a primary reason and an additional 24 percent noted it as a secondary reason.) The survey is based on telephone interviews conducted in 2009 with 614 young adults aged 22 to 30 years old who have experience with some post-secondary education.
} 
path to graduation and stay committed to that plan. Students who lack clear goals and a genuine understanding of why college is important often become derailed by relatively minor challenges and setbacks (Grubb, 2006).

Postsecondary institutions are unfortunately not always set up to handle this collection of problems. ${ }^{7}$ Deming (2017) puts it succinctly: "less-selective public institutions often have large classes and provide little in the way of academic counseling, mentoring, and other student supports (page 6.)" Bound, Lovenheim, and Turner (2010) find that shifts in the types of institutions students attend toward lower-ranked, public schools along with declines in institutional resources per student are more important than shifts in student characteristics in explaining the decline in college completion rates between the 1970s and 1990s. Deming and Walters (2017) compare the impact of changes in tuition and changes in spending on enrollment and degree completion in US public postsecondary institutions between 1990 and 2013. Their analysis finds that spending increases are more effective per-dollar than price cuts in terms of increasing completion rates. This finding is consistent with a view that institutional resources are a critical component to driving student completion rates. It is also the case that over recent decades, colleges and universities have experienced declining state appropriations alongside rising enrollment, leading to fewer resources per student.

In this paper, we report the results from a randomized controlled trial (RCT) investigation of a comprehensive case management intervention that was designed to help low-income students overcome the myriad obstacles that might threaten their persistence in community college. The program, Stay the Course (STC), offers case management services provided by a social service agency that are substantially more intensive than what community college academic counselors tend to provide. Each STC student is paired with a trained social worker, called a navigator, who offers students

\footnotetext{
${ }^{7}$ In their book "Making College Work," Holzer and Baum (2017) outline a number of institutional weaknesses that might hinder the success of disadvantaged students attending public universities and community colleges and they discuss a number of possible policy and programmatic remedies.
} 
coaching, mentoring, and referral services. Navigators work with students to help them overcome their individual barriers to college completion such as finding affordable child care, selecting courses that keep them on track towards graduation, making decisions about transferring to four-year colleges, and locating social services in the community. In addition, students in the STC program have access to limited emergency financial assistance (EFA) that can be used for non-academic expenses that could negatively impact their persistence in college.

The RCT demonstration was rolled out in the fall of 2013 at the Trinity River Campus of Tarrant County College (TCC) in Fort Worth, Texas. Eligible students were randomly assigned to one of two treatment groups or a control group. Treatment group 1 was offered the full STC comprehensive case management treatment including referrals, mentoring, coaching, and access to EFA; treatment group 2 was offered access to EFA only; and the control group received no special services. We use administrative records to track academic outcomes for study participants for three years post random assignment. We find no difference in outcomes between the EFA-only treatment group and the control group.

The results indicate that the full STC comprehensive case management program significantly increased persistence and degree completion through six semesters, especially for female students. Estimated effects are imprecise for the full sample, but intention-to-treat estimates for females show a 7.4 percentage point (3.3 percentage point standard error) increase in the likelihood of earning an associate's degree off a control group mean of 15.7 percent. This translates into a treatment-on-thetreated effect of 31.5 percentage points (14.1 percentage point standard error). Based on the estimated earnings premium for individuals with community college credentials, we estimate that the earnings gains associated with the program (for the full sample) exceed program costs in just over four years.

The completion crisis has led to a number of interventions designed to increase college persistence and completion rates and this paper contributes to this literature. One group of studies include interventions designed to address the issue of academic under-preparation among community 
college students, ${ }^{8}$ generally with disappointing results (Long, 2014; Martorell and McFarlin, 2011). An evaluation of the Bottom Line intervention, a long-term college advising program offered to lowincome students beginning in high school, found positive effects on early college persistence. While Bottom Line provides some social supports, such as helping students acclimate to college, the intervention focuses on advising students, the bulk of whom attend 4-year college, through the college and financial aid application process and offering some academic advising while in college (Barr \& Castleman, 2017). More closely related to our paper, there are a number of well-designed studies investigating whether enhanced student support services and/or mentoring can lead to improved educational outcomes for college students. The evidence is mixed. Two of the sites that were part of MDRC’s “Opening Doors" demonstration project focused on enhanced student services. Students were given two semesters of access to counselors with much smaller caseloads than the traditional caseload of 1000 students per counselor. The evaluation found no improvements in ultimate academic outcomes (Scrivener and Weiss, 2009). Angrist, Lang, and Oreopoulos (2009) found that first-year female students (but not males) at a large 4-year public school in Canada demonstrated improved academic outcomes in terms of GPA and credits earned when they had access to peer advising and organized study groups as part of the Project STAR intervention, but only when those services were combined with merit-based financial incentives. Bettinger and Baker (2014) found that college students randomly assigned to student coaches with the InsideTrack program have higher persistence and completion rates, but this program did not focus on low-income students or a community college setting.

The most promising results to date have been found for the comprehensive Accelerated Study in Associates Program (ASAP) at the City University of New York, which offered tuition waivers,

\footnotetext{
${ }^{8}$ About 60 percent of students entering community college are referred to at least one remedial education class (Bailey, 2009; Attewell et al., 2006). Community colleges devote upwards of $\$ 2$ billion annually towards these developmental education programs (Strong American Schools, 2008).
} 
enhanced student services, and special course offerings, among other innovations. The evaluation found that this three-year program nearly doubled graduation rates (Scrivener et al., 2015). It should be noted that this program is multi-faceted and extremely expensive, which raises questions about how readily such a program might be replicated in other settings. Our study complements this existing work by investigating whether a comprehensive case management program delivered by a social service provider, as opposed to a school counselor, can lead to increased completion rates for very low income students in a community college.

As a policy matter, the federal government spends billions of dollars a year subsidizing community college attendance. In 2015 , the Pell Grant program provided $\$ 30$ billion in aid for lowincome individuals to attend college. More than a third of Pell recipients attend community college (Baime and Mullin, 2011). States and local governments often provide financial aid and need-based scholarships as well. Identifying successful ways to better realize the potential of the community college investment, both for the students themselves and for society more generally, is of paramount research and policy importance. ${ }^{9}$

\section{THE “STAY THE COURSE” INTERVENTION}

Stay the Course is a comprehensive case management intervention that was designed by Catholic Charities Fort Worth (CCFW) to help low-income community college students address personal obstacles so they can persist in school and complete their intended degree. CCFW is a large nonprofit social service provider with a mission to improve outcomes for low-income families and individuals. They provide services to over 100,000 unduplicated clients each year.

\footnotetext{
${ }^{9}$ Improving persistence in community college was an explicit priority of the Obama administration, which launched the American Graduation Initiative with a goal of producing 5 million more community college graduates by 2020. http://www.whitehouse.gov/blog/Investing-in-Education-The-American-Graduation-Initiative.
} 


\section{A. Features of the intervention}

Upon enrollment in STC, a student is assigned to a trained social worker called a "navigator" who serves as their case manager. The navigator meets with the student initially to conduct a client assessment that identifies the client's long-term goals, likely barriers to these goals, and their strengths and weaknesses. The student and navigator then collaboratively develop and implement a comprehensive service plan that sets out the steps necessary for the student to accomplish their educational goals. The service plan is tailored to devise intermediate goals for the student to accomplish along the way, discuss the action steps necessary to accomplish these goals within established timeframes, and address potential barriers through a range of available services. Action steps are developed for each specified goal in the service plan. For example, if a participant has a goal of earning a grade of at least a " $\mathrm{B}$ " in a specific course, the action steps for that goal might include attending all classes for the course or meeting once a week with a tutor. The service plan is reviewed and updated every 90 days. The construction of the service plan is a time-consuming but important process in that it helps build trust between the navigator and the client. The service provider's view is that for case management to work students must feel comfortable coming to the navigator to help solve intimate and personal problems, e.g., domestic violence, substance abuse, mental illness, etc.

Participation in the program involves comprehensive case management services for the student on an ongoing basis. There are four main components to these services: referrals, mentoring, coaching, and emergency financial assistance. The navigators refer STC participants to a variety of resources within the TCC system such as access to tutors, financial aid, etc., as well as to external resources outside the college such as employment and child-care services, health services, government programs and benefits such as SNAP, and other social services (Ybarra, 2016). ${ }^{10}$ Mentoring involves the process

\footnotetext{
${ }^{10}$ As part of the RCT evaluation, we collaborated with an independent, qualitative researcher to conduct an implementation study of Stay the Course at the Trinity River Campus, which is available as Ybarra (2016). This study drew from interviews of STC staff in the spring of 2015 and 60 hours of observations of all aspects of STC staff work in the fall of 2015, about two years after the launch of the evaluation.
} 
of navigators developing a personal relationship of trust with each of their student clients. This sort of personal relationship is likely different from the typical relationship that academic advisors at community colleges have with their students, as college advisors tend to have caseloads that are in the hundreds or thousands of students (as compared to 34 for STC navigators) and have a different professional orientation toward educational and academic counseling, as opposed to social work. To establish this mentoring relationship, navigators encourage open communication and build trust so that students are engaged in the program and they continue to seek the navigator's advice on educational and personal issues that affect their progress in school.

In the coaching component of comprehensive case management, the navigator and student have ongoing meetings to work on resolving unforeseen problems that might threaten the ability of the student to complete their degree. Students might encounter situations along many dimensions that could derail their education, such as problems with housing, child-care arrangements, transportation, or work schedules. Students are encouraged from the outset to meet with their navigator for help addressing such circumstances. The thought behind the implementing agency's approach is that the stronger is the trust between the navigator and the student, the more likely it is that the student will come to the navigator to discuss personal issues that might inhibit success in school. Another feature of the coaching component is helping students navigate the community college system. Navigators remind students to register for the necessary and appropriate classes. Depending on student need, navigators may also assist students in finding campus-provided tutors and help students avail themselves of campus-provided services.

The implementing agency emphasizes that personal interactions, as opposed to emails or phone calls, are at the heart of their approach to comprehensive case management. Program guidelines recommend that navigators and students meet in person at least once per month. ${ }^{11}$ However, case notes

\footnotetext{
11 At the launch of the study in fall 2013 there were no explicit benchmarks in place requiring navigators to meet with students a certain number of times per week or month. The frequency of meetings was at the discretion of the navigator and
} 
data reveal that the frequency of in-person interactions varied widely. Table 1 reports summary statistics of all navigator/student interactions as reported in the navigator case notes. On average, navigators interacted with their clients about 34 times each semester. About half of these interactions were via text or email and about a third were over the phone. There were an average of 4.1 in-person meetings per semester, with a typical duration of 41 minutes. The frequency and type of navigator-student interactions did not differ noticeably by gender.

Figure 1 shows the frequency of discussion topics covered during navigator-student interactions based on these electronic case notes. We include as navigator-student interactions in-person meetings, phone calls, or individualized emails/texts, but not mass communication such as group emails or administrative reminders. Academic discussion topics such as class registration and gaining access to tutors were the most popular; they were discussed in over a third of the interactions between navigators and students. Ten of the next 11 most frequent topics have little to do with academics but rather, are aspects about the student's life outside of school, such as work, transportation, health, child care, etc. Work/employment issues were discussed in nearly a quarter of all interactions, which is consistent with the evidence that this issue is one that often leads low-income students to drop out of community college (Johnson et al., 2011). Students discussed referrals to other specialized service programs in almost 17 percent of their interactions with their navigators. Housing, finances, and transportation were each mentioned in at least 12 percent of interactions. The one other academic issue included among the 12 most frequent topics is transferring to a four-year college, which was discussed in 11 percent of interactions.

The fourth component of comprehensive case management is access to emergency financial assistance (EFA). Students in the STC program are eligible to apply for EFA for non-academic

student. In the spring of 2015, the program supervisor set explicit benchmarks for navigator-student interactions to ensure fidelity of program implementation. These benchmarks included reciprocal contact (email, text, phone) at least once per week, in-person meetings every two weeks, and completion of a service planning goal once every three weeks (Ybarra 2016). 
expenses or income shortfalls that could negatively impact a student's persistence in college. EFA is not meant to constitute an academic grant or scholarship, but rather, to provide the buffer resources that a low-income student might need to address personal issues and stay in school. The motivation for this assistance is that for many low-income community college students, small negative shocks like a family emergency, higher than expected child-care costs, a necessary vehicle repair, or not having a security deposit for a new apartment, can sometimes have lasting impacts on academic outcomes. It is widely recognized in other contexts many low-income families live perpetually on the brink of crisis and deep hardship (Barr and Blank 2009; Shipler 2008). Bertrand et al., (2004) describe this aspect of poverty in terms of some families having "narrow margins for error." The EFA is designed to reduce the vulnerability to negative shocks that many low-income families experience.

To receive EFA, students must successfully demonstrate both that they have an imminent financial need and that not meeting this need would be detrimental to their academic progress. Additional factors that determine whether the event would qualify for assistance include the extent to which the event is foreseeable, controllable, and temporary. Examples of qualified costs include a car repair, rent and utilities, a bus pass, or emergency medical care. Eligibility for EFA is restricted to those students with a cumulative GPA of a 2.0 or higher at TCC (unless they are in their first semester) and those enrolled in at least 9 credits the semester in which they apply. An individual student could apply to receive up to $\$ 500$ per semester, capped at $\$ 1,500$ total over a three-year period. A program Funds Coordinator makes determinations for all EFA applications, subject to a supervisor's review. Navigators may assist clients in completing the financial assistance application, but they do not attend the student's meeting with the Funds Coordinator nor do they intercede with the Funds Coordinator on behalf of the student. This separation is designed to keep navigators from having to deny financial assistance from their own clients.

Based on Funds Coordinator records, over a three-year period, students enrolled into the STC treatment group $(\mathrm{N}=94)$ submitted 126 requests for $\mathrm{EFA}$, of which 82 percent were approved, with 
an average payout of $\$ 276$. As shown in Figure 2, 29 percent of the requests granted were for transportation needs, 23 percent for housing, 33 percent for utilities, and 15 percent for other (school supplies, child care, etc.). About half of the students in the program never applied for any funds, and less than 10 percent of students collected more than $\$ 1,001$ over the three-year period. After six semesters, only one STC student had collected the max amount of $\$ 1,500$.

\section{B. Comparisons to similar interventions}

STC differs from existing interventions designed to increase college completion. The STC intervention differs from these other programs in several important ways. Table 2 facilitates a comparison of features across programs by highlighting the key aspects of four other interventions evaluated with RCTs alongside STC. We highlight a few unique characteristics of the STC case management approach here. First, STC comprehensive case management services are more involved and intensive than those typically available at community colleges, as well as those that have been offered in previous demonstration projects. ${ }^{12}$ The services extend beyond academic counseling as navigators work with each student to develop a personal relationship of trust and help them address their unique social, financial, academic, and personal impediments to college success. Second, the case management services provided by STC are provided by trained social workers working for a non-profit agency outside the community college system. Third, the caseloads for STC navigators are much lower than those of the typical community college guidance counselor, and are even considerably smaller than those found in the other highlighted demonstration projects. Fourth, the STC case management services also include access to emergency financial assistance for non-tuition financial impediments. ${ }^{13}$

By way of contrast, the coaching provided as part of the Inside'Track program is limited to telephone-based coaching. Though coaches also work to help students overcome non-academic "real

\footnotetext{
12 A study conducted by the American College Counseling Association found that over half of community colleges have counselor to student ratios between 1:1500 and 1:3500 (Gallagher, 2010).

13 Ultimately, our results suggest that providing EFA alone does not improve academic outcomes. However, this evidence does not imply that EFA, offered as part of case management services, is ineffective.
} 
life" barriers, it is unlikely that they develop the type of personal mentoring relationships that the STC navigators work to build. The enhanced student counseling services implemented as part of the "Open Doors" demonstration were short-term, limited to two semesters, and delivered by college counselors who did not necessarily have the expertise in dealing with the non-academic issues that trained social workers help clients address. The enhanced student services in the ASAP program were provided by community college counselors, who may or may not have offered as much dedicated attention to life barriers and outside referrals as the STC case managers, but more importantly, in the ASAP program, those services are embedded in a much larger set of intervention features, including tuition waivers, blocked classes, and special courses and registration access on campus.

\section{THE RANDOMIZED CONTROL TRIAL}

\section{A. The Research Design}

To determine the impact of this comprehensive case management program on persistence and degree completion, we implemented a randomized controlled trial (RCT) evaluation at Tarrant County College (TCC), a large community college in Fort Worth, Texas enrolling more than 50,000 students in associate degree and technical programs across five campuses. TCC students typically come from disadvantaged backgrounds and have very high dropout rates. Among first-time, degree-seeking students who entered in fall 2011, only 14.8 percent earned a degree in four years and only 2.6 percent graduated in two years. The leadership at TCC is aware of this challenge and readily agreed to partner with the research team and service provider on this intervention and evaluation. TCC provided dedicated space for the navigators to meet privately with students and provided us with the necessary administrative data to evaluate the program and to perform the randomization. 
The universe for the sample consisted of the 8,849 students currently enrolled at the Trinity River campus of TCC in the fall semester of $2013 .{ }^{14}$ The research demonstration project took place at a single campus because it was more feasible for CCFW to implement this new intervention on a single campus. RCT eligibility was limited to students who met the following criteria: 1) enrolled in at least 9 credit hours at TCC; 2) degree seeking; 3) age 18 years or older; 4) satisfied at least 1 Texas Success Initiative (TSI) standard; ${ }^{15}$ 5) newly enrolled or have earned a Cumulative GPA of at least 2.0 at TCC to date; 6) accumulated less than 30 credit hours at TCC to date; and 7) Pell eligible or fall below 200\% of the poverty line (based on reported income on the FASFA). Eligibility criteria (1) through (5) are intended to target students who may feasibly complete a degree in three years. The credit cap in eligibility criteria (6) is meant to target students who might be at risk of dropping out; a student with more than 30 credits is perceived to be successfully on a path to graduation. The final eligibility rule is to target the sample to low-income students. Imposing these eligibility criteria left us with a final study sample of 1,168 students.

Table 3 reports summary statistics on all community college students at the national and state level, all TCC Trinity River Campus students, and finally, STC study participants. Overall, TCC students are similar to other community college students around the nation, with the exception of TCC enrolling considerably more Hispanic and part-time students. STC participants differ from typical TCC students and the average community college student in a few important ways. STC students are more likely to be female, and are on average more than two years younger than other TCC students. Students in the study are much more likely to be full time when compared to the rest of the TCC campus and

\footnotetext{
14 The Trinity River campus, located in downtown Fort Worth, Texas, enrolls nearly 9,000 students each year. It offers primarily Associate of Arts (AA) degrees, which requires 60 credit hours to complete. Some of the larger programs housed at the Trinity River campus include Nursing, Surgical Technology, Physical Health Information Technology, Sign Language, and Service Learning.

15 TCC students are given placement examines (TSIs) in three subjects: math, reading and writing. Failure to pass the TSI in a subject means that a student starts their community college career in a remedial version of that subject.
} 
much more likely to receive Pell grants when compared to the national average, differences driven by the eligibility criteria described above.

At the close of the academic enrollment period on August 20, 2013, the Office of Institutional Intelligence and Research (OIIR) at TCC extracted data necessary to identify the eligible sample $(\mathrm{N}=$ 1,168). ${ }^{16}$ The research team used these data to randomly assign eligible students into one of three groups. The randomization procedure is displayed in Figure 3. 430 students were offered the STC treatment, which included case management and EFA. Another 299 students were assigned to an EFA-only treatment, while 439 students were assigned to a control group. Students in this final group received no additional services, but still had full access to any existing college or community services, just as they would in the absence of this intervention. The study includes two treatment arms to help determine how much of the effectiveness of the fully implemented program could be achieved with only the financial assistance feature. ${ }^{17}$ The EFA treatment group is smaller because the provider had limited resources to provide this separate treatment arm.

After randomly assigning each eligible student to one of the three groups, the research team notified TCC of the results and the college sent specific emails and letters by regular mail, signed by the president of the college, to each student selected for the different treatment groups. ${ }^{18}$ These emails and letters introduced the program and explained that the student had been randomly selected to participate. TCC also sent a data file to CCFW containing student IDs, names and contact information. In these communications, selected students were directed to a web page to electronically sign a consent

\footnotetext{
${ }^{16}$ We have continued to enroll and randomize additional students into STC in more recent semesters, but this paper will focus on the fall 2013 cohort, as this is the only group for which we currently have outcome data six semesters after enrollment.

17 The EF-only treatment is most comparable to the "Dreamkeepers" program created by Scholarship America (https://scholarshipamerica.org/dreamkeepers/). That program provides monetary assistance to students who face shortterm financial emergencies. A descriptive review conducted by MDRC examined the outcomes of recipients of Dreamkeepers funds from 11 different schools in the 2004-2006 period and found that recipients have "disproportionate need" and were "more academically challenged" than the average student, but their reenrollment rates were roughly comparable to other students (Geckeler et al., 2008). Though the findings of that report are consistent with the notion that limited financial assistance can promote persistence, the MDRC study was not an RCT, and the comparisons reported should not be interpreted as indicative of a causal effect of the program.

${ }_{18}$ Copies of these emails and letters are included in the appendix to the paper.
} 
form for services and enroll in the program (http://www.staythecourse-cc.org/). Of the 430 students offered the STC treatment, 94 students completed the intake process to enroll in STC a take-up rate of 22 percent. The EFA treatment group had 126 students enroll, reflecting a take-up rate of 42 percent.

The low take up rate of the program appears to have been a feature of the way the RCT was rolled out. We randomly assigned a treatment/control group status to all eligible students and then invited them via mailed letters and emails to visit a website and enroll. ${ }^{19}$ In the second phase of the program, we reversed the order and invited all eligible students to visit a website and enroll, and then after enrolling in the demonstration project, students were randomly assigned to a treatment or control group. This reversed procedure led to a take-up rate of 87.3 percent. We thus do not view the low takeup rate in phase 1 to suggest that the program itself does not hold appeal to students. That said, it is likely the case that a new program that is not familiar to students will have a lower take-up rate in early years as compared to an established program with a reputation on campus as a legitimate source of support. Importantly, these issues do not threaten the internal validity of the study in any way, but they are relevant to considerations of how to most effectively roll out such a program and reach the intended population of students.

Table 4 provides descriptive information about the students in the study for both treatment groups and the control group for the fall of 2013. As shown by the p-values in columns 4 and 5 , in all cases the data fail to reject the hypothesis that the mean characteristics are the same, when comparing either of the treatment groups to the control group, indicating that the randomization procedure generated appropriate balance across groups.

\section{B. Data and Methods}

Our empirical analysis relies on student-level administrative school records provided to us from TCC. A few months after the end of each semester, OIIR at TCC sent the research team a file

\footnotetext{
19 The college would not allow us to text students on mobile devices.
} 
containing the student baseline characteristics that were used to determine eligibility, additional characteristics used in the analyses, and academic outcomes. Through TCC we were able to link these records to data from the National Student Clearinghouse (NSC), which allows us to observe whether a student transfers to a two- or four-year college and completes a degree at another post-secondary institution. ${ }^{20}$

The outcomes we consider include:

- Enrolled in College: An indicator for whether a student was enrolled in classes at TCC or any other NSC reporting institution at the start of the relevant semester, which is defined as spring 2016 in six-semester results, spring 2015 in four-semester results, and spring 2014 in twosemester results. For the two- and four-semester results, we will also look at enrollment at TCC as a separate outcome as fewer students have transferred to a different college by that point.

- Total Credits Earned: The cumulative number of college credits that a student has earned by the end of the relevant semester. Because we only observe credits earned for students while they are enrolled at TCC, we impute credits for students who are enrolled elsewhere using the average credits earned by students in the study who are still enrolled at TCC in the current semester.

- Cumulative GPA: Cumulative TCC GPA by the end of the relevant semester.

- Earned any Degree: An indicator for whether a student earned a degree (certificate, associate's, or bachelor's) at TCC or any other NSC reporting institution by the end of the relevant semester.

\footnotetext{
20 The National Student Clearinghouse is a nonprofit organization that works with more than 3,600 post-secondary institutions to provide data on student enrollment and degree completion. The NSC participating colleges enroll $98 \%$ of all post-secondary students in the U.S. (http://www.studentclearinghouse.org/about/).
} 
- Earned an Associate's Degree: An indicator for whether a student earned an associate's degree at TCC or any other NSC reporting institution by the end of the relevant semester. ${ }^{21}$

Because we are utilizing random assignment, we measure the impact of STC by comparing outcomes for students in the treatment and control groups. We estimate the differences in outcomes using a standard intent-to-treat (ITT) model:

$$
y_{i}=\beta_{0}+T_{i} \beta_{1}+\mathbf{X}_{i} \beta_{2}+\varepsilon_{i}
$$

where $\mathrm{y}_{\mathrm{i}}$ is an indicator for one of our outcome measures for student $i$ in the semester of interest, $\mathrm{T}$ equals 1 if the respondent is in the relevant treatment group and zero otherwise, and $\varepsilon_{\mathrm{i}}$ is an individuallevel error term that is assumed to be i.i.d. The vector $\mathbf{X}_{\mathrm{i}}$ includes a set of person-level characteristics: age, age squared, gender, whether a student is Black, Asian or a different race, whether the student is Hispanic, the number of basics skills assessments the student has passed at entry, family income, and family income squared from the student's FASFA form. When measuring the effect of the full STC intervention, the estimation sample includes the STC treatment group and the control group; it excludes students in the EFA treatment group. When measuring the effect of EFA, the estimation sample includes the EFA treatment group and the control group; it excludes students in STC treatment group.

Our main results focus on outcome measures six semesters after enrollment in the study, but to examine how any impact of the intervention changes over time, we also report some shorter-term results. Because many students assigned to the treatment groups do not participate in services (the takeup rate was 22 percent for the STC treatment group and 42 percent for the EFA treatment group), we

\footnotetext{
${ }^{21}$ While we also have data on whether a student has completed a certificate or a bachelor's degree, we do not report these outcomes separately because they occur infrequently - after 6 semesters less than 3 percent of the sample had obtained a certificate, and just over 1 percent had obtained a BA degree.
} 
also estimate the effect of the intervention for those who participate, or the treatment-on-the-treated (TOT) effect. Specifically, we estimate:

$$
\mathrm{yi}_{\mathrm{i}}=\gamma_{0}+\mathrm{P}_{\mathrm{i} \gamma_{1}}+\mathbf{X}_{\mathrm{i} \gamma_{2}}+\eta_{\mathrm{i}}
$$

where $\mathrm{P}_{\mathrm{i}}$ is an indicator for participation in the program. We estimate these effects via an instrumental variable (IV) model, using assignment to treatment $\left(\mathrm{T}_{\mathrm{i}}\right)$ as an instrument for participation in the program $\left(\mathrm{P}_{\mathrm{i}}\right)$. Program participation (or take-up) is defined as attending the intake meeting and completing an intake form.

\section{SIX SEMESTER RESULTS}

Table 5 reports the six-semester results associated with the STC intervention. We report results for the full sample, as well as separately by gender. For each outcome, we report both ITT and TOT effects. As a benchmark for the magnitude of these effects, we report the mean of each outcome for the control group in the IT'T columns and the control complier mean (CCM) in the TOT columns. The CCM is calculated as the mean of the outcome for the compliers (those who take-up the treatment) in the treatment group less the IV estimate. ${ }^{22}$

STC has a large effect on persistence in school after six semesters, but the estimate is only significant at the 10 percent level. The point estimate indicates that students in the treatment group are 5.6 percentage points more likely to be enrolled in school after six semesters. The TOT estimate indicates that those who participate in STC are 25.1 percentage points more likely to persist, more than double the CCM. For the full sample, all the other estimates are positive, indicating improved outcomes for the treatment group, but none of these estimates are statistically significant.

\footnotetext{
${ }^{22}$ For binary outcomes, sampling variation can produce negative estimates of the CCM. For these cases we report the CCM as zero, following (Kling, Liebman, and Katz, 2007). To determine the nature of selection into take-up based on observable characteristics, we examine the mean characteristics of treatment compliers and non-compliers respectively (Appendix Table 1). Students who take up the program tend to be slightly older, but overall the mean characteristics of compliers and noncompliers are very similar. We observe that those who take up the program have a slightly lower propensity score of earning a degree ex ante, though the difference is not statistically significant.
} 
The positive effect of STC is driven by females. Females assigned to the STC treatment group are 8.4 percentage points more likely to still be enrolled in college after six semesters than females in the control group, and this difference is statistically significant. The TOT estimate (35.8 percentage points) indicates that female program participants were nearly four times more likely to persist in college relative to the CCM. Through six semesters, we also see that females in the treatment group have accumulated more total credits, although this effect is only marginally significant.

There is a large and statistically significant effect on completing an associate's degree for females. Three years after enrollment in the study, females in the treatment group are 7.4 percentage points more likely to have completed an associate's degree than females in the control group, corresponding to a TOT effect of 31.5 percentage points. There is little evidence of a positive effect of STC participation for male students, and at the $10 \%$ level, we can reject the hypothesis that the effect is the same for females and males.

We also investigate whether there are heterogeneous treatment effects by other key student characteristics. Table 6a reports results separately for white and non-white students and separately for those with family income above and below the STC sample median $(\$ 18,500)$. Those in the STC treatment group with family income greater than the median family income of the study sample are 8.3 percentage points (standard error 4.8) more likely to stay enrolled in classes anywhere through their sixth semester (Table 6a, column 3), which implies a TOT effect of 44.1 percentage points. The ITT estimate on this same outcome for students with lower levels of family income implies a much smaller, 2.4 percentage point increase (standard error 4.7). Given the standard errors, we cannot reject similar effects across income groups.

The estimated effects for non-white students are generally similar to what we report for the full sample in Table 5, which is not surprising given that about 70 percent of the sample is non-white. The estimated TOT effect for non-white students implies a 31.8 percentage point increase in the likelihood of being enrolled anywhere after six semesters (standard error 18.1). When we limit the sample to 
whites, the estimated TOT estimate is very small (2.3 percentage points) but with a standard error ten times that size. Given the large standard error associated with that estimate, we cannot reject the null that there are similar effects by race.

In the first four columns of Table $6 \mathrm{~b}$, we report estimates based on whether students had more or fewer initial credit hours than the median at enrollment (10 credit hours). Our motivation for looking separately by credit hours was to observe whether students who were further along the education process had a different treatment effect. Perhaps students with more credits when enrolled may not need as much help because they were further along. Alternatively, these same students might be more likely to be on the margin of completing a degree, and comprehensive case management provides the critical support needed to graduate. Point estimates indicate large TOT effects for both groups but neither are statistically significant. Overall, the data do not indicate any persistent differences across students based on this simple cut of the data.

In the second half of the table, we consider whether results vary based on "outcome propensity," or the estimated probability to achieve a particular outcome of interest (i.e. earning a degree) based on baseline characteristics. We implement the repeated split sampling (RSS) method proposed by Abadie et al. (2013). ${ }^{23}$ Under RSS, the control group is randomly divided in half and one half of the group is used to generate the prediction equation. These estimates are applied to the treatment group and the other half of the control group. This split sample is repeated multiple times. The estimated treatment effect is the simple average across these iterations. Standard errors are calculated by bootstrap subsamples of the split samples. In Abadie et al. (2013), the first-stage equation is estimated by OLS for the outcome regardless of whether the outcome is continuous or dichotomous. This equation is called the prognosis score. In our work, we use a logit model when the outcome of

\footnotetext{
${ }^{23}$ This method builds on the practice of testing for heterogeneous treatment effects by propensity score, where the propensity score for the full sample is constructed based on estimated betas from an initial comparison group. Abadie et al. (2013) demonstrate that this approach is systematically biased in favor of finding the largest effects for the lowest probability group.
} 
interest is dichotomous and generate a propensity score, and use the prognosis score when the outcome is continuous. We use 1000 split samples to calculate means and a 100 bootstrap iterations for each split sample to calculate standard errors.

Results for the subsamples indicate that STC is particularly effective for students with higher baseline propensity scores of success. Among those in the top tercile of propensities to be enrolled in school, students assigned to the STC treatment group are 11.8 percentage points more likely to still be enrolled in college after six semesters (TOT estimate 65.7 with a standard error of 29.9). For those in the top tercile, STC also appears to increase total accumulated credits and the likelihood of earning a degree, but these estimates are only statistically significant at the 10 percent level. In general, the results for those in the lower and middle thirds indicate that STC had little effect on academic outcomes for these groups (Table 6b, column 5-8). However, given the large standard errors on the estimated treatment effects these subgroups, we cannot reject the hypotheses that the effects of STC is the same across terciles.

All of the analysis discussed up to this point has focused on the differences in outcomes between the STC treatment group, which was offered comprehensive case management and access to emergency financial assistance, and the control group. Our research design also allows us to directly estimate the effect of providing only emergency financial assistance, by comparing the EFA treatment group to the control group. We report these results in Table 7 for the same outcomes reported above. After six semesters, those who had access to emergency financial assistance earned degrees and remained enrolled in classes at remarkably similar rates to the control group. We find no statistically significant differences in outcomes in the overall sample or for the male and female subsamples. In nearly all cases, the point estimates are small, and in many cases they are negative. However, given the standard errors we are unable to reject the hypothesis of small positive effects.

Although this evidence suggests that EFA itself does not have a sizeable impact on persistence and degree completion in community college, this does not mean that EFA is not an effective 
component of comprehensive case management. We have not tested case management with EFA against case management without EFA, which is what would be needed to draw such a conclusion.

\section{TWO- AND FOUR-SEMESTER RESULTS}

Because we have received outcome data from TCC each semester, we are able to examine how the impact of STC evolves over time. Comparing short- and medium-term outcomes helps us understand whether the intervention has an immediate impact or whether effects appear more gradually. Many community college students drop out after just one or two semesters, so an intervention like STC has the potential to affect outcomes nearly immediately. In our study sample, about 20 percent of students drop out by the end of the second semester.

Table 8 reports two semester results for the same five outcomes as reported after six semesters in Table 5, plus the additional outcome of whether the student is enrolled at TCC. We do not report this outcome with the six-semester results because by six semesters after enrollment in the study many students have transferred to a different school. After just two semesters, however, less than 1.5\% of the study sample is enrolled at a post-secondary institution other than TCC, so enrollment at TCC captures college enrollment status for most of the students.

The data indicate that after two semesters not enough time has passed for students to obtain a degree-only 0.7 percent of the control group has completed a degree by this point. It is not surprising that we find no effect on degree completion for the full sample or for the female and male subsamples. However, the data indicate that two semesters is enough time to observe an effect on intermediate outcomes. The TOT estimate for enrolled in classes at TCC indicates that STC participation leads to a 28.9 percentage point increase (standard error 12.1). In terms of gender comparisons, the data already start to show some indication that the effect is stronger for females. When looking at whether the student is enrolled anywhere, however, we do not see a noticeable difference between the treatment and control groups after two-semesters. It appears that after only two semesters, STC is effective at 
keeping kids from transferring from TCC, but not necessarily at increasing overall persistence in community college. We also find that the treatment group has accumulated more credits. STC participants have nearly 5 more credit hours (the equivalent of 1.66 additional classes), but this difference is marginally significant.

Table 9 reports four-semester results, which includes the summer between years one and two, a time during which many community college students drop out. This is evident in our four-semester results, by which point more than half the sample is no longer at TCC, and only about three-fifths of the sample is still enrolled in school. After four semesters, we still see the positive effect on credit hours that was evident after two semesters. However, we still see no effect of STC on degree completion or enrollment at any college, and we no longer see an effect of STC on enrollment at TCC.

Together, our results after two, four, and six semesters indicate that the intervention did not have a meaningful impact on enrollment in college or degree completion until after six semesters. This suggests that the STC intervention is more effective at keeping students in school after they have been enrolled for several semesters than it is at preventing dropouts in the short-run. Perhaps this is because it takes time for the navigators and students to develop the relationship that allows comprehensive coaching and mentoring to have a substantive impact on persistence and completion, so the impact of these efforts on success in school is not evident until after a few years.

Another possible explanation is related to the implementation of the program. Throughout the course of this intervention, the provider has been monitoring what services the navigators provide and the form of the interactions in an effort to ensure fidelity of implementation. In the Spring 2015 semester, the provider re-emphasized to the navigators the importance of regular, direct interaction with their students, and case notes indicate a rise in student-navigator interactions after this point. This increased engagement may have contributed to the impact of the program after six semesters. 


\section{DISCUSSION}

\section{A. Estimated benefit-to-cost ratio}

Because STC is a "heavy touch" intervention with relatively high per-student costs, it is important to consider the positive effects of the program alongside the costs. The total cost per student for three years of STC case management (including access to EFA) is $\$ 5,640$, or $\$ 1,880$ per year. ${ }^{24}$ This cost includes STC staff salary (manager, navigators, and an EFA coordinator), fringe benefits, training, and EFA payouts. To measure program benefits, we plan to follow the students in this RCT demonstration project for additional years and link their student records to administrative earnings records. We will then compare the causal impact estimates on earnings to the program costs. However, until enough time has elapsed, we cannot calculate a benefit-to-cost ratio based on realized earnings. Instead, we conduct a back-of-the-envelope calculation using average earnings differences observed in national survey data.

The TOT estimate for the full sample from Table 5 indicates that STC increased the probability an enrolled client received an associate's degrees by 16 percentage points. Data from the 2015 five-year American Communities Survey (ACS) for individuals age 25-39 indicate that those with an associate's degree earn about $\$ 7,050 /$ year more than people with less than a year of college education. ${ }^{25}$ In addition, the TOT estimate suggests that STC participation increases enrollment in school after six semesters by 25 percentage points. Some of this increase is the result of students who persist in order to obtain a degree, so we net out the additional persistence that comes from degree completion (i.e. $0.25-0.16=0.09)$, and assume greater persistence means enrolling in college beyond one year. This implies that for each additional treated student who does not earn an associate's degree, 0.09 more students persist in school beyond one year. The same ACS data used above show that individuals with

\footnotetext{
24 This cost estimate assumes that each navigator has a caseload of 34 .

25 We use the IPUMS.org version of the ACS (Ruggles et al., 2015).
} 
at least a year of college (without an associate's degree) earn about $\$ 2,200$ more than people with less than a full year of college.

Combining these estimated returns to community college with our estimates from the full sample indicates that treating an additional student increases annual earnings by $0.16 * \$ 7,050+$ $0.09 * \$ 2,200=\$ 1,326$. Comparing this benefit to the total three-year program cost of $\$ 5,640$, indicates that program costs are offset by increased earnings in about 4.25 years. This estimate overstates the pay-back period as it does not allow for the possibility that those with an associate's degree eventually earn a bachelor's degree. Nor does it consider benefits to a degree beyond earnings. On the other hand, this simple calculation only accounts for direct program costs, and does not attempt to consider the opportunity cost of any foregone wages while attending schools. Making such adjustments will lead to a pay-back period that is larger or smaller, but the main takeaway will remain, which is that the costs of this program are fairly small as compared to a reasonable assumption about lifetime earnings increases associated with higher educational attainment.

\section{B. Additional interpretation issues}

The results for STC raise three critical questions. First, why is there strong evidence of a positive effect for females, but not for males? Second, why did the EFA program not yield any discernible benefits? Third, are these results replicable? We offer some speculative observations here.

The finding of sizable positive effects of this intervention for females but no statistically significant effects for males is consistent with findings from other similar types of interventions. Angrist et al. (2009) found a larger positive effect of the Project STAR intervention for females. Carroll and Sacerdote (2017) implemented a college-going mentoring programs for high school students, focusing on helping more students enroll in college, and found that the program leads to large increases in college enrollment rates among female students, but much smaller effects for males. Like those authors, we can only speculate as to what might be driving the difference. One obvious issue in the STC evaluation is that all case managers in the program were female. This was not by design, but rather 
a consequence of the social work profession, from which STC navigators are drawn, being overwhelmingly dominated by females. Perhaps a program that so heavily relies on personal connection is more effective when the mentor/mentee pair is of the same gender. ${ }^{26}$

We conjectured that perhaps females would be more likely to meet with their case managers, both because they would be more comfortable talking with a female and because they would have been more likely to have participated in safety net programs and interacted with a case manager previously. Females are slightly more likely than males to take-up the offer of participating in STC $23.3 \%$ versus $19.3 \%$ ), but case notes on student/navigator interactions reveal little difference in these interactions by gender. Male students appear no less likely to have met with their navigator than female students. Still, perhaps females were more likely to take navigator's advice to heart, even if they received advice in roughly equal measure. Future implementations of the program would benefit from the recruitment of male caseworkers to the navigator role so that this hypothesis could be explored. However, all this should be considered with the caveat that the results for males are statistically imprecise. There may, in fact, have been a positive effect for some males. A large sample size of treated male students would likely yield better insight into whether this type of a program tends to be effective for male students.

The finding of no discernible benefit associated with access to EFA without associated case management raises the possibility that such an intervention is only effective if it is offered in conjunction with additional services. These results suggest that giving very low income students access to cash aid without the requirement or benefit of having a case manager to help address the causes of the underlying financial distress is not sufficient. Perhaps with a less disadvantaged population, a onetime infusion of cash could help, but for students in our low-income sample, we found no evidence that having access to up to $\$ 1,500$ to cover non-tuition financial shocks increased either enrollment

\footnotetext{
${ }^{26}$ Interestingly, the ASAP program yielded similar benefits for men and women. But as described above, that program is not just a case management program, but also includes tuition benefits and academic and classroom features. The contrast between the gender similarity in the ASAP program and the gender differences in the mentoring programs suggests that the greater effect for females is specific for mentoring programs.
} 
persistence or degree attainment. We also stress that our study is not able to shed light on whether EFA is a critical aspect of case management. There might be important interactions between the coaching and mentoring aspects of STC and the ability of case managers to offer limited financial help. This is something future work should investigate.

Replicability is a key concern with any successful but small scale RCT. STC was designed with the goal of subsequent replication. The research team has worked closely with our implementing partners over the past three years to document the key aspects of the program such as how to train navigators and how much to expect to pay in the way of EFA so the program can be replicated. We are collaborating with the implementing agency partner, CCFW, to roll out the program in an RCT context on other college campuses in Fort Worth. In addition, we are in the process of working with other social service agencies outside of Fort Worth to implement the program with an RCT research design on other campuses. It will be instructive to investigate whether the results are reproduced with a different implementing agency, with a different student population, and in a different community college setting.

A related replication question is whether it is fundamental to the effectiveness of the intervention that the program is implemented by a third-party non-profit rather than community college counselors. We offer the observation that the implementing agency, CCFW, considers individualized case management to be their comparative advantage. To the best of our understanding, this tends not to be the particular focus or training of community college counselors. Perhaps that dedicated focus is what makes this application of the program so effective. If individuals without a background in social work, or with a different background in social work, were to serve as navigators, the results might be different. Again, this points to a need for replication to learn under what contexts specifically such a program can be expected to generate beneficial effects for students. 


\section{CONCLUSION}

This paper has investigated whether a case-management intervention could increase the rates of enrollment persistence and degree completion among low-income community college students. To study this question, we conducted an RCT evaluation of the STC intervention. The main elements of this program are comprehensive case management - including mentoring, coaching, referrals, and limited access to emergency financial assistance - conducted by a trained social worker with a caseload of no more than 34 students at a time. The paper has described an RCT evaluation of this program implemented by the research team in partnership with a local social service agency at a community college campus in Fort Worth, Texas.

The results indicate sizable increases in school persistence and degree completion through six semesters, driven by female students. Intention-to-treat estimates based on regression-adjusted differences between females randomly assigned to case management services and those randomly assigned to a control group show a 7.4 percentage point increase in the likelihood of earning an associate's degree (standard error of 3.3), off a control group mean of 15.7 percent. This translates into a treatment-on-the-treated effect of 31.5 percentage points (standard error of 14.1).

Point estimates for the full sample of females and males combined are positive, but not statistically significant. We report a back-of-the-envelope calculation that takes as program benefits the point estimates for the full sample combined with projected earnings increases. This simple calculation suggests that the benefits of the program, as captured by increased earnings, exceeds the per-student costs $(\$ 5,640$ total for three years of enrollment) after only 4.25 years in the workforce post schooling. There is no evidence of a positive effect of a limited version of the program that only offered access to emergency financial assistance (EFA) without associated case management services. We offer speculative explanations above for why the program was particularly effective for females and why the EFA-only treatment did not lead to positive outcomes. 
This paper contributes to multiple literatures. First, it contributes to the literature on college completion, in particular, the sets of studies focusing on ways to increase college completion rates among low-income students. As noted in the introduction, income gaps in college completion have widened despite expansions to the Pell Grant program that have made financial aid more generous for low-income families. Research and policy attention to this challenge has tended to focus on interventions run through community colleges themselves, in particular, academic programs and enhanced school counseling. The research demonstration project studied in this paper is novel in that it is an comprehensive case-management program run by a third party non-profit with a particular expertise in case management.

The paper contributes more generally to the literature on anti-poverty strategies and ways to effectively help individuals achieve economic self-sufficiency. This paper has demonstrated that case management can be a cost-effective way to increase rates of educational persistence and degree completion among poor and near poor students. Future work will follow these same students to investigate longer term effects on earnings. A supplementary project being conducted by a subset of the research team is investigating the effectiveness of case management in improving a wide variety of economic outcomes for a non-student population in the same community. Together, this body of research will contribute to our collective knowledge about the types of barriers facing low-income individuals and the most cost-effective ways of helping them achieve economic security. 


\section{References}

Abadie, Alberto, Matthew M. Chingos, and Martin R. West. Endogenous stratification in randomized experiments. No. w19742. National Bureau of Economic Research, 2013.

Angrist, Joshua, Daniel Lang, and Phil Oreopoulos. 2009. "Incentives and Services for College Achievement: Evidence from a Randomized Trial." American Economic Joumal: Applied Economics 1(1): 136-163.

Attewell, P., Lavin, D., Domina, T., \& Levey, T. (2006). New evidence on college remediation. The Journal of Higher Education, 77(5), 886-924.

Bailey, Thomas, Davis Jenkins, and Timothy Leinbach. 2005. "What We Know About Community College Low-Income and Minority Student Outcomes: Descriptive Statistics from National Surveys." Columbia University, Teachers College, Community College Research Center.

Bailey, Thomas. 2009. "Challenge and Opportunity: Rethinking the Role and Function of Developmental Education in Community College." New Directions for Community Colleges 2009(145): 11-30.

Barr, Andrew, and Benjamin Castleman. 2017. "The Bottom Line on College Counseling." Working Paper.

Barr, Michael and Rebecca Blank. 2009. Insufficient Funds: Savings, Assets, Credit, and Banking Among Low-Income Households. New Rork: Russell Sage Foundation.

Baime, D. S., \& Mullin, C. M. (2011). Promoting educational opportunity: The Pell Grant program at community colleges. Washington, DC: AACC Policy Brief.

Baum, Sandy, and Judith Scott-Clayton. 2013. "Redesigning the Pell Grant Program for the TwentyFirst Century." The Hamilton Project, Discussion Paper 2013-04.

Bertrand, Marianne, Sendhil Mullainathan, and Eldar Shafir. 2004. "A Behavioral-Economics View of Poverty." American Economic Review 94(2): 419-423.

Bettinger, Eric P., and Rachel B. Baker. 2014. "The Effects of Student Coaching: An Evaluation of a Randomized Experiment in Student Advising." Educational Evaluation and Policy Analysis 36(1): 319.

Bound, John, Michael Lovenheim, and Sarah Turner. 2010. "Why Have College Completion Rates Declined? An Analysis of Changing Student Preparation and Collegiate Resources," American Economic Journal: Applied Economics 2: 129-157.

Carrell, Scott and Bruce Sacerdote. 2017. "Why do college-going interventions work?” American Economic Journal: Applied Economics 9(3): 124-151.

Deming, David. 2017. "Increasing College Completion with a Federal Higher Education Matching Grant." The Hamilton Project.

Deming, David and Christopher Walters. 2017. “The Impact of Price Caps and Spending Cuts on U.S. Postsecondary Attainment,” NBER working paper 23736.

"Diploma to Nowhere." Strong American Schools. (2008).

Gallagher, Robert. 2010. "National Survey of Counseling Center Directors 2010.” The International Association of Counseling Services, Inc. 
Geckeler, Christian, Carrie Beach, Michael Pih, and Leo Yan. 2008. "Helping Community College Students Cope with Financial Emergencies: Lessons from the Dreamkeepers and Angel Fund Emergency Financial Aid Programs." DMRC.

Grubb, W. Norton. 2006. "'Like, what do I do now?': The Dilemmas of Guidance Counseling." In T. Bailey and V. Morest (Eds.), Defending the Community College Equity Agenda. Baltimore, MD: Johns Hopkins University Press, 195-222.

Hiler, Tamara, and Lanae Erickson Hatalsky. 2016. “What Free Won’t Fix: Too Many Public Colleges are Dropout Factories.” Third Way.

Holzer, Harry and Sandy Baum. 2017. "Making College Work: Pathways to Success for Disadvantaged Students.” Washington DC: Brookings Institution Press.

Jepsen, Christopher, Troske, Kenneth and Coomes, Paul. 2014. "The Labor-Market Returns to Community College Degrees, Diplomas, and Certificates.” Journal of Labor Economics, 32, issue 1, p. $95-121$.

Johnson, Jean, Jon Rochkind, Amber Ott, and Samantha DuPont. 2011. "With Their Whole Lives Ahead of Them: Myths and Realities About Why So Many Students Fail to Finish College." Public Agenda. http:// files.eric.ed.gov/fulltext/ED507432.pdf

Kane, Thomas, and Cecilia Rouse. 1995. "Labor-Market Returns to Two and Four-Year College." American Economic Review 1983(3): 11-30.

Kling, Jeffrey R., Jeffrey B. Liebman, and Lawrence F. Katz. 2007. "Experimental Analysis of Neighborhood Effects." Econometrica 75(1): 83-119.

Long, Bridget Terry. 2014. "Addressing the Academic Barriers to Higher Education," in Policies to Address Poverty in America, ed. Melissa S. Kearney and Benjamin H. Harris. Brookings Institution, The Hamilton Project.

Marcotte, Dave E., Thomas Bailey, Carey Borkoski, and Greg S. Kienzl. 2005. "The Returns of a Community College Education: Evidence from the National Education Longitudinal Survey." Educational Evaluation and Policy Analysis, v 27, n.2, pp 157-176.

Marcotte, Dave. 2016. "The Returns to Education at Community Colleges: New Evidence from the Education Longitudinal Survey." IZA Discussion Papers 10202, Institute for the Study of Labor (IZA).

Martorell, Paco and Isaac McFarlin Jr. 2011. "Help or Hindrance? The Effects of College Remediation on Academic and Labor Market Outcomes," The Review of Economics and Statistics, 93:2, 436-454.

National Student Clearinghouse. 2017. Web site: www.studentclearinghouse.com.

Richburg-Hayes, Lashawn, et al. "Rewarding persistence: Effects of a performance-based scholarship program for low-income parents." (2009).

Ruggles, Steven, Katie Genadek, Ronald Goeken, Josiah Grover, and Matthew Sobek. Integrated Public Use Microdata Series: Version 6.0 [dataset]. Minneapolis: University of Minnesota, 2015. http://doi.org/10.18128/D010.V6.0.

Scott-Clayton, Judith. 2011. "The Shapeless River: Does a Lack of Structure Inhibit Students' Progress at Community Colleges." Columbia University, Teachers College, Community College Research Center Working Paper No. 25. 
Scrivener, Susan, Michael J. Weiss, Alyssa Ratledge, Timothy Rudd, Colleen Sommo and Hannah Freaques. 2015. "Doubling graduation rates: Three-year effects of CUNY's Accelerated Study in Associate Programs (ASAP) for Developmental Education Students."

Scrivener, Susan, and Michael J. Weiss. 2009. "More Guidance, Better Results?: Three-Year Effects of an Enhanced Student Services Program at Two Community Colleges." New York: MDRC.

Shipler, David K. The working poor: Invisible in America. Vintage, 2008.Stevens, Ann H., Michael Kurlaender, and Michel Grosz. 2015. "Career Technical Education and Labor Market Outcomes: Evidence from California Community Colleges.” NBER Working Paper 21137.

U.S. Department of Education. 2016. National Center for Education Statistics, NCES-2016-112rev. "Postsecondary Institutions and Cost of Attendance in 2015-16; Degrees and Other Awards Conferred, 2014-15; and 12-Month Enrollment”: https://nces.ed.gov/pubs2016/2016112rev.pdf.

U.S. Department of Education. 2013. National Center for Education Statistics, NCES-2013-037. "The Condition of Education 2013." https:// nces.ed.gov/pubs2013/2013037.pdf.

U.S. Department of Education. 2010. National Center for Education Statistics, NCES-2011-151: "Persistence and Attainment of 2003-04 Beginning Postsecondary Students: After 6 Years": https://nces.ed.gov/pubs2011/2011151.pdf.

van der Steeg, Marc, Roel van Elk, Dinand Webbink. 2015. "Does Intensive Coaching Reduce School Dropout? Evidence from a Randomized Experiment." Economics of Education Review 48(October): 184-197.

Ybarra, Marci. 2016. “An Implementation Study of Stay the Course, 2013-2015.” University of Chicago Working Paper. 


\section{Appendix: Correspondence used to enroll study participants into treatment}

The following letters and emails were sent to eligible students who were assigned to one of the two treatment arms. The letters were printed on Trinity River letterhead and mailed in TCC marked envelopes. The emails were sent via the college's mass communication system and therefore appeared to the students as emails from TCC. The initial letters and emails are below. Similar emails reminding eligible students about the opportunity to participate were sent periodically throughout the enrollment window.

\section{Solicitation Emails}

Email 1 (Sent to the students assigned to the full Stay the Course treatment):

Dear Student,

You have been selected to participate in an exciting new opportunity at Trinity River Campus called Stay the Course. Designed to help students persist in school and attain their degrees, this program is being offered at no cost to you through a partnership with Catholic Charities Fort Worth, a major non-profit in the Fort Worth community. Stay the Course is part of a research project, and due to limited funding, only a small number of Trinity River students have been selected to participate. Through a lottery, you were chosen to participate. Eligibility for this program cannot be transferred to another student.

As a participant in Stay the Course, you will have the opportunity to work with a Navigator on campus to assist you in dealing with the many obstacles that students often face as they progress through college. The Navigator will also work with you to develop a personalized Path to Graduation.

Another tremendous benefit of Stay the Course is access to financial assistance to assist you in overcoming unexpected financial hardships that threaten your ability to stay enrolled in school. If you enroll in the program, you will be eligible for up to $\$ 500$ of assistance per semester, with a cap of $\$ 1500$ that you can receive over the next three years of enrollment at TCC.

To sign up, please visit the Stay the Course website at staythecourse-cc.org. Your unique login information for the site is as follows:

USERNAME: Student ID \# PASSWORD: [...]

To participate in Stay the Course, you must sign up by September 9, 2013. If you would like to remove yourself from our contact list, you can opt-out of the program at any time by logging into the Stay the Course website and selecting "opt out."

To learn more, please attend one of the Stay the Course information sessions in the Speed Room (TRTR 4207, $4^{\text {th }}$ Floor) on the Trinity River Campus on August $28^{\text {th }}$ at 9 am or August $\mathbf{2 9}^{\text {th }}$ at 4pm. Light refreshments will be served. Stay the Course staff will be there to explain how the 
program works and to help you enroll. In the meantime, if you have any questions about the program, please contact the Stay the Course staff at [\#].

We at Trinity River Campus are excited to be the first TCC campus participating in this program and encourage you to take full advantage of this unique opportunity.

Sincerely,

[College President]

Email 2 (Sent to the students assigned to the Emergency Financial Assistance only treatment):

Dear Student,

You have been selected to participate in an exciting new opportunity at Trinity River Campus called Stay the Course Fund. The program is designed to assist students in overcoming unexpected financial hardships that threaten their ability to stay enrolled in school. It is being offered at no cost to you through a partnership with Catholic Charities Fort Worth, a major non-profit in the Fort Worth community. Stay the Course Fund is part of a research project, and due to limited funding, only a small number of Trinity River students have been selected to participate. Through a lottery, you were chosen to participate. Eligibility for this program cannot be transferred to another student.

As a participant in Stay the Course Fund, you will have access to financial assistance to help you overcome unexpected financial hardships that threaten your ability to stay enrolled in school. If you enroll in the program, you will be eligible for up to $\$ 500$ of assistance per semester, with a cap of $\$ 1500$ that you can receive over the next three years of enrollment at TCC. If you would like to be eligible for this $\$ 1500$ of financial assistance, you must enroll in Stay the Course Fund by September 9, 2013.

To sign up, first visit the Stay the Course Fund website at staythecourse-cc.org. Your unique login information for the site is as follows:

USERNAME: Student ID \# PASSWORD: [...]

To complete the enrollment process, you must pick up a Stay the Course Fund welcome packet. These packets are available on the Trinity River Campus in room TREF 6402 during normal business hours. If you would like to remove yourself from our contact list, you can opt-out of the program at any time by logging into Stay the Course Fund website and selecting "opt out."

To learn more, please attend one of the Stay the Course Fund information sessions in the Speed Room (TRTR 4207, $4^{\text {th }}$ floor) on the Trinity River Campus on August $\mathbf{2 8}^{\text {th }}$ at $4 \mathbf{p m}$ or August $29^{\text {th }}$ at 9am. Light refreshments will be served. Stay the Course Fund staff will be there to explain how the program works and to help you enroll. You may also pick up your welcome packet at this event. In the meantime, if you have any questions about the program, please contact the Stay the Course Fund staff at [\#]. 
We at Trinity River Campus are excited to be the first TCC campus participating in this program and encourage you to take full advantage of this unique opportunity.

Sincerely,

[College President]

\section{Solicitation Letters}

Letter 1 (Sent to the students assigned to the full Stay the Course treatment):

Dear Student,

This letter is to follow up on an email you recently received regarding your eligibility to participate in an exciting new opportunity at Trinity River Campus called Stay the Course. This program is designed to help students persist in school and attain their degrees. It is being offered at no cost to you through a partnership with Catholic Charities Fort Worth, a major non-profit in the Fort Worth community. Stay the Course is part of a research project, and due to limited funding, only a small number of Trinity River students were selected to participate. Through a lottery, you were chosen to participate. Eligibility for this program cannot be transferred to another student.

As a participant in Stay the Course, you will have the opportunity to work with a Navigator who is here to assist you in dealing with the many obstacles that students often face as they progress through college. The Navigator will also work with you to develop a personalized Path to Graduation.

Another tremendous benefit of Stay the Course is access to financial assistance to help you overcome unexpected financial hardships that threaten your ability to stay enrolled in school. If you enroll in the program, you will be eligible for up to $\$ 500$ of assistance per semester, with a cap of $\$ 1500$ that you can receive over the next three years of enrollment at TCC.

To enroll, please visit the Stay the Course website at staythecourse-cc.org. Your unique login information for the site is as follows:

USERNAME: Student ID \#

PASSWORD: [...]

To participate in Stay the Course, you must enroll by September 9, 2013. If you would like to remove yourself from our contact list, you can opt-out of the program at any time by logging into the Stay the Course website and selecting "opt out." 
To learn more, please attend one of the Stay the Course information sessions in the Speed Room (TRTR 4207, $4^{\text {th }}$ Floor) on the Trinity River Campus on August $28^{\text {th }}$ at 9 am or August $29^{\text {th }}$ at 4pm. Light refreshments will be served. Stay the Course staff will be there to explain how the program works and to help you enroll. In the meantime, if you have any questions about the program, please contact the Stay the Course staff at [\#].

We at Trinity River Campus are excited to be the first TCC campus participating in this program and encourage you to take full advantage of this unique opportunity.

Sincerely,

[TCC President]

Letter 2 (Sent to the students assigned to the Emergency Financial Assistance only treatment):

Dear Student,

This letter is to follow up on an email you recently received regarding your eligibility to participate in an exciting new opportunity at Trinity River Campus called Stay the Course Fund. This program is designed to assist students overcome financial hardships they may face during their college careers. It is being offered at no cost to you through a partnership with Catholic Charities Fort Worth, a major non-profit in the Fort Worth community. Stay the Course Fund is part of a research project, and due to limited funding, only a small number of Trinity River students have been selected to participate. Through a lottery, you were chosen to participate. Eligibility for this program cannot be transferred to another student.

As a participant in Stay the Course Fund, you will have access to financial assistance to help you overcome unexpected financial hardships that threaten your ability to stay enrolled in school. If you enroll in the program, you will be eligible for up to $\$ 500$ of assistance per semester, with a cap of $\$ 1500$ that you can receive over the next three years of enrollment at TCC. If you would like to be eligible for this $\$ 1500$ of financial assistance, you must enroll in Stay the Course Fund by September 9, 2013.

To enroll, first visit the Stay the Course Fund website at staythecourse-cc.org. Your unique login information for the site is as follows:

USERNAME: Student ID \#

PASSWORD: enrollme

Further, you must pick up a Stay the Course Fund welcome packet. These packets are available on the Trinity River campus in room TREF 6402 during normal business hours. If you would like to remove yourself from our contact list, you can opt-out of the program at any time by logging into the Stay the Course Fund website and selecting "opt out." 
To learn more, please attend one of the Stay the Course Fund information sessions in the Speed Room (TRTR 4207, $4^{\text {th }}$ floor) on the Trinity River Campus on August $28^{\text {th }}$ at $4 \mathbf{p m}$ or August $29^{\text {th }}$ at 9am. Light refreshments will be served. Stay the Course Fund staff will be there to explain how the program works and to help you enroll. You may also pick up your welcome packet at this event. In the meantime, if you have any questions about the program, please contact the Stay the Course Fund staff at [\#].

We at Trinity River Campus are excited to be the first TCC campus participating in this program and encourage you to take full advantage of this unique opportunity.

Sincerely,

[College President] 
Table 1

Summary of Navigator-Student Interactions for the STC Program

\begin{tabular}{|c|c|c|c|}
\hline \multirow[b]{2}{*}{ Variable } & \multicolumn{3}{|c|}{ Mean per Student } \\
\hline & Overall & Females & Males \\
\hline Total Interactions per Semester & $\begin{array}{c}33.81 \\
(16.39)\end{array}$ & $\begin{array}{c}33.61 \\
(16.04)\end{array}$ & $\begin{array}{c}34.17 \\
(17.11)\end{array}$ \\
\hline In-Person Meetings per Semester & $\begin{array}{c}4.13 \\
(3.65)\end{array}$ & $\begin{array}{c}3.75 \\
(3.18)\end{array}$ & $\begin{array}{c}4.85 \\
(4.33)\end{array}$ \\
\hline Duration of In-Person Meeting (Minutes) & $\begin{array}{c}41.25 \\
(25.96)\end{array}$ & $\begin{array}{c}43.19 \\
(25.90)\end{array}$ & $\begin{array}{c}38.44 \\
(25.43)\end{array}$ \\
\hline Text/Email Interactions per Semester & $\begin{array}{l}17.08 \\
(9.99)\end{array}$ & $\begin{array}{c}17.81 \\
(10.15)\end{array}$ & $\begin{array}{l}15.71 \\
(9.56)\end{array}$ \\
\hline Phone Interactions per Semester & $\begin{array}{c}9.70 \\
(11.64)\end{array}$ & $\begin{array}{c}9.23 \\
(11.49)\end{array}$ & $\begin{array}{c}10.59 \\
(11.91)\end{array}$ \\
\hline Duration of Phone Meeting (Minutes) & $\begin{array}{c}12.35 \\
(20.35)\end{array}$ & $\begin{array}{c}11.57 \\
(19.79)\end{array}$ & $\begin{array}{c}13.76 \\
(21.27)\end{array}$ \\
\hline Number of Students & 94 & 63 & 31 \\
\hline
\end{tabular}


Table 2

Characteristics of Select RCT Interventions Promoting College Persistence or Completion

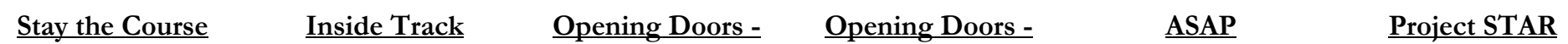

\begin{tabular}{|c|c|c|c|c|c|c|}
\hline \multicolumn{7}{|c|}{ Louisiana } \\
\hline Reference & - & $\begin{array}{c}\text { Bettinger \& Baker, } \\
2014\end{array}$ & $\begin{array}{c}\text { Scrivener \& Weiss, } \\
2009\end{array}$ & $\begin{array}{c}\text { Richburg-Hayes et } \\
\text { al., } 2009\end{array}$ & Scrivener et al., 2015 & $\begin{array}{c}\text { Angrist, Lang, } \\
\text { Oreopoulis, } 2009 .\end{array}$ \\
\hline RCT Demonstration & $\begin{array}{l}\text { Fort Worth, TX. } \\
2013-2016 \\
(\mathrm{~N}=869)\end{array}$ & $\begin{array}{l}\text { Multiple anonymous } \\
\text { locations. 2003-2004, } \\
\text { 2007-2008 }(\mathrm{N}= \\
13,555)\end{array}$ & $\begin{array}{l}\text { Multiple sites. } \\
\text { 2003-2006 }(\mathrm{N}= \\
2,139)\end{array}$ & $\begin{array}{l}\text { New Orleans, LA. } \\
2004-2005 \\
(\mathrm{~N}=1,019)\end{array}$ & $\begin{array}{l}\text { New York, NY. } \\
2010-2013 \\
(\mathrm{~N}=896)\end{array}$ & $\begin{array}{l}\text { Canada. } \\
2005-2006 \\
(\mathrm{~N}=1,656)\end{array}$ \\
\hline Type of Institution & $\begin{array}{l}\text { Community college } \\
\text { (one campus) }\end{array}$ & $\begin{array}{l}\text { Private, public, two- } \\
\text { year, and four-year }\end{array}$ & $\begin{array}{l}\text { Community college } \\
\text { (two campuses) }\end{array}$ & $\begin{array}{l}\text { Community college } \\
\text { (two campuses) }\end{array}$ & $\begin{array}{l}\text { Community college } \\
\text { (three campuses) }\end{array}$ & $\begin{array}{l}\text { Public 4-year } \\
\text { university (one } \\
\text { campus) }\end{array}$ \\
\hline Cost per Student & $\begin{array}{l}\$ 5,640 \text { total for three } \\
\text { years of enrollment }\end{array}$ & $\$ 500$ per semester & $\begin{array}{l}\text { Cost analysis not } \\
\text { included }\end{array}$ & $\begin{array}{l}\text { Cost analysis not } \\
\text { included }\end{array}$ & $\begin{array}{l}\$ 16,284 \text { in additional } \\
\text { services above } \\
\text { control group } \\
(\$ 42,065 \text { total) for } \\
\text { three year program }\end{array}$ & $\begin{array}{l}\$ 739 \text { for one year } \\
\text { program }\end{array}$ \\
\hline Primary Finding & $\begin{array}{l}31.5 \text { pp increase in } \\
\text { associate's degree } \\
\text { completion among } \\
\text { enrolled women, } \\
\text { nearly } 3 \text { times the } \\
\text { graduation rate of } \\
\text { females in the } \\
\text { control group }\end{array}$ & $\begin{array}{l}\text { Coached students } 3 \\
\text { to } 4 \text { pp more likely } \\
\text { to persist after } 18 \\
\text { mos, } 24 \text { mos; } 4 \text { pp } \\
\text { more likely to } \\
\text { graduate }\end{array}$ & $\begin{array}{l}\text { No sig. increase in } \\
\text { credits ended or over } \\
\text { the } 3 \text {-year follow-up } \\
\text { period }\end{array}$ & $\begin{array}{l}6.5 \mathrm{pp} \text { increase in } \\
\text { persistence thru } 4 \\
\text { semesters post } \\
\text { random assignment }\end{array}$ & $\begin{array}{l}18 \text { pp increase in } \\
\text { degree completion, } \\
\text { nearly } 2 \text { times the } \\
\text { graduation rate of } \\
\text { students in the } \\
\text { control group }\end{array}$ & $\begin{array}{l}\text { GPA improvement } \\
\text { \& increase in credits } \\
\text { earned for first-year } \\
\text { female students (but } \\
\text { not males) in the full } \\
\text { SFSP program }\end{array}$ \\
\hline $\begin{array}{l}\text { Eligible student } \\
\text { population }\end{array}$ & $\begin{array}{l}\text {-Pell eligible or } \\
\text { below } 200 \% \text { FPL } \\
\text {-Must be enrolled in } \\
\text { at least } 9 \text { credit hours } \\
\text { at baseline } \\
\text { - } 30 \text { or fewer } \\
\text { accumulated credits } \\
\text { at baseline }\end{array}$ & None & $\begin{array}{l}\text {-Below } 250 \% \text { FPL } \\
\text {-Full-time or part- } \\
\text { time } \\
-12 \text { or fewer } \\
\text { accumulated credits } \\
\text { at baseline }\end{array}$ & $\begin{array}{l}\text {-Parents of at least } \\
\text { one dependent child } \\
\text { under } 19 \text { with } \\
\text { household income } \\
\text { below } 200 \% \text { FPL. } \\
\text { - Full-time or part- } \\
\text { time } \\
\text { - No students with } \\
\text { degrees or } \\
\text { occupational }\end{array}$ & $\begin{array}{l}\text {-Pell eligible or } \\
\text { below 200\% FPL. } \\
\text {-Restricted to all } \\
\text { majors except: allied } \\
\text { Health Sciences, Pre- } \\
\text { Clinical Nursing, } \\
\text { Forensic Science, } \\
\text { and Engineering } \\
\text { Science } \\
\text { - Full-time only }\end{array}$ & $\begin{array}{l}\text { - No income } \\
\text { restrictions } \\
\text { - Full-time only } \\
\text { - Entering first-year }\end{array}$ \\
\hline
\end{tabular}




\begin{tabular}{|c|c|c|c|c|c|c|}
\hline & & & & $\begin{array}{l}\text { certificate from } \\
\text { accredited college or } \\
\text { university }\end{array}$ & $\begin{array}{l}\text { - } 12 \text { or fewer } \\
\text { accumulated credits } \\
\text { at baseline }\end{array}$ & \\
\hline \multicolumn{7}{|l|}{ Case management } \\
\hline $\begin{array}{l}\text { Coaching, } \\
\text { Mentoring, } \\
\text { Referrals }\end{array}$ & $\begin{array}{l}\text { Intensive case } \\
\text { management, } \\
\text { involving, coaching, } \\
\text { mentoring, and } \\
\text { referrals for all } \\
\text { aspects of the } \\
\text { student's life. } \\
\text { Emphasis on in- } \\
\text { person meetings }\end{array}$ & $\begin{array}{l}\text { Coaching by phone } \\
\text { to help student } \\
\text { develop time } \\
\text { management, self- } \\
\text { advocacy, and study } \\
\text { skills }\end{array}$ & $\begin{array}{l}\text { Counselor assists } \\
\text { with personal and } \\
\text { academic issues. } \\
\text { Counselor refers } \\
\text { students to services } \\
\text { on and off campus }\end{array}$ & $\begin{array}{l}\text { Coaching and } \\
\text { referral services } \\
\text { available but } \\
\text { underutilized }\end{array}$ & $\begin{array}{l}\text {-Comprehensive } \\
\text { coaching from an } \\
\text { ASAP-dedicated } \\
\text { adviser. } \\
\text {-Career information } \\
\text { from an ASAP- } \\
\text { dedicated career and } \\
\text { employment services } \\
\text { staff member }\end{array}$ & $\begin{array}{l}\text {-Peer mentoring } \\
\text { from upper-class } \\
\text { students in the same } \\
\text { field of study at the } \\
\text { University. } \\
\text {-Peer Advisors were } \\
\text { trained to identify } \\
\text { circumstances that } \\
\text { called for more } \\
\text { professional help } \\
\text { and to make } \\
\text { appropriate referrals }\end{array}$ \\
\hline $\begin{array}{l}\text { Student:Counselor } \\
\text { Ratio }\end{array}$ & $34: 1$ & Not reported & $\begin{array}{l}\text { Lorain Campus: } \\
81: 1 ; \\
\text { Owens Campus: } \\
\text { 157:1 }\end{array}$ & $\begin{array}{l}\text { Varied, but rarely } \\
\text { exceed 100:1 }\end{array}$ & $\begin{array}{l}\text { Between 80:1 and } \\
60: 1\end{array}$ & Not reported \\
\hline $\begin{array}{l}\text { Educational } \\
\text { Planning/Advising }\end{array}$ & $\begin{array}{l}\text { Navigator helps } \\
\text { student identify goals } \\
\text { and steps necessary } \\
\text { to achieve those } \\
\text { goals }\end{array}$ & $\begin{array}{l}\text { The coach works } \\
\text { with the student to } \\
\text { develop a clear } \\
\text { vision of his/her } \\
\text { goals and set up } \\
\text { steps necessary to } \\
\text { achieve those goals }\end{array}$ & $\begin{array}{l}\text { Counselor helps with } \\
\text { work-based, learning } \\
\text { efforts, juggling } \\
\text { school and work, } \\
\text { and career } \\
\text { aspirations }\end{array}$ & $\begin{array}{l}\text { Available but } \\
\text { underutilized }\end{array}$ & $\begin{array}{l}\text { Students enroll in an } \\
\text { ASAP seminar } \\
\text { covering topics such } \\
\text { as goal-setting, study } \\
\text { skills, and academic } \\
\text { planning }\end{array}$ & $\begin{array}{l}\text { Peer advisors e- } \\
\text { mailed advisees at } \\
\text { least biweekly to } \\
\text { solicit questions } \\
\text { about university } \\
\text { assimilation, } \\
\text { scheduling, studying, } \\
\text { and time } \\
\text { management }\end{array}$ \\
\hline \multicolumn{7}{|l|}{ Financial Supports } \\
\hline $\begin{array}{l}\text { Non-tuition Financial } \\
\text { Assistance }\end{array}$ & $\begin{array}{l}\text { Students with a GPA } \\
\text { of } 2.0 \text { or above are } \\
\text { eligible up } \$ 500 \text { of } \\
\text { emergency financial } \\
\text { assistance a semester, } \\
\text { capped at } \$ 1,500\end{array}$ & No & $\begin{array}{l}\text { Students are eligible } \\
\text { for a } \$ 150 \text { stipend } \\
\text { per semester for two } \\
\text { semesters, usable for } \\
\text { any purpose }\end{array}$ & No & $\begin{array}{l}\text { Students receive free } \\
\text { use of textbooks and } \\
\text { free MetroCards for } \\
\text { use on public } \\
\text { transportation, } \\
\text { contingent on } \\
\text { participation in the } \\
\text { program. }\end{array}$ & No \\
\hline
\end{tabular}




\begin{tabular}{|c|c|c|c|c|c|c|}
\hline Tuition Waivers & No & No & No & No & $\begin{array}{l}\text { 3-11 percent of } \\
\text { students received } \\
\text { waiver in a given } \\
\text { semester }\end{array}$ & No \\
\hline Grade Bonus & No & No & No & $\begin{array}{l}\$ 250 \text { after midterms } \\
\text { contingent on } \\
\text { staying enrolled at } \\
\text { least halftime \& } \\
\text { earning passing } \\
\text { grades; } \$ 500 \text { upon } \\
\text { completion of } \\
\text { courses with a } C \\
\text { average or better. } \\
\text { Extended for two } \\
\text { semesters; students } \\
\text { can earn up to } \\
\$ 2,000 \text {. }\end{array}$ & No & $\begin{array}{l}\text { Substantial cash } \\
\text { awards, up to } \$ 5,000 \text {, } \\
\text { for meeting a target } \\
\text { GPA. }\end{array}$ \\
\hline \multicolumn{7}{|l|}{ Academic } \\
\hline $\begin{array}{l}\text { Learning } \\
\text { Communities/ Block } \\
\text { Classes }\end{array}$ & No & No & No & No & $\begin{array}{l}\text { Students enroll in } \\
\text { blocked or linked } \\
\text { courses in their first } \\
\text { year. Students can } \\
\text { register for courses } \\
\text { early so that they can } \\
\text { create convenient } \\
\text { schedules and get } \\
\text { seats in the courses } \\
\text { they need }\end{array}$ & No \\
\hline
\end{tabular}


Table 3

Descriptive Characteristics of Community College Students

\begin{tabular}{lcccc}
\hline \hline & U.S. & Texas & TCC & $\begin{array}{c}\text { Full Stay the } \\
\text { Course Sample }\end{array}$ \\
Variable & $(1)$ & $(2)$ & $(3)$ & $(4)$ \\
\hline Age & 28.00 & & 26.92 & 24.21 \\
Under 30 years old & 0.71 & 0.719 & 0.750 & 0.833 \\
30 years old and over & 0.28 & 0.280 & 0.251 & 0.167 \\
Female & 0.57 & 0.558 & 0.579 & 0.655 \\
Male & 0.43 & 0.442 & 0.421 & 0.345 \\
White, non-Hispanic & 0.51 & 0.342 & 0.389 & 0.273 \\
Black, non-Hispanic & 0.14 & 0.132 & 0.181 & 0.198 \\
Asian/Pacific Islander & 0.06 & 0.044 & 0.044 & 0.031 \\
Other Race & 0.09 & 0.062 & 0.033 & 0.030 \\
Hispanic & 0.19 & 0.420 & 0.354 & 0.468 \\
Part Time & 0.60 & 0.748 & 0.869 & 0.446 \\
Full Time & 0.40 & 0.252 & 0.131 & 0.554 \\
Receive Pell Grants & 0.33 & & & 0.986 \\
First Generation College Student & 0.36 & & & 0.583 \\
N & 7.3 million & 700,963 & 8,849 & 869 \\
\hline \hline
\end{tabular}

Notes: National statistics are taken from the American Association of Community Colleges (AACC) 2014 Fact Sheet. Texas statewide statistics were collected from txhighereddata.org. The TCC statistics represent averages from the Trinity River Campus in Fall 2013. Due to the limited age data available, the age ranges for the TCC column are under 31 and 31 and over. For students in the Stay the Course sample, full time students are defined as students who are enrolled in 12 or more credits at the Fall 2013 census date. 
Table 4

Mean Characteristics of Treatment Groups and Control Group, Fall 2013

\begin{tabular}{|c|c|c|c|c|c|}
\hline \multirow[b]{2}{*}{ Variable } & \multicolumn{3}{|c|}{ Means by Group Assignment } & \multicolumn{2}{|c|}{$\begin{array}{c}\text { P-value on Test that Means are the } \\
\text { Same Across Groups }\end{array}$} \\
\hline & $\begin{array}{c}\text { STC } \\
\text { Treatment } \\
(1) \\
\end{array}$ & $\begin{array}{c}\text { EFA } \\
\text { Treatment } \\
(2) \\
\end{array}$ & $\begin{array}{c}\text { Control } \\
\text { (3) }\end{array}$ & $\begin{array}{c}\text { STC \& } \\
\text { Control } \\
(4)\end{array}$ & $\begin{array}{c}\text { EFA \& } \\
\text { Control } \\
(5)\end{array}$ \\
\hline Age at Entry & 24.09 & 24.865 & 24.33 & 0.664 & 0.388 \\
\hline Female & 0.628 & 0.642 & 0.681 & 0.099 & 0.272 \\
\hline TSI's Remaining at Entry & 0.537 & 0.525 & 0.572 & 0.477 & 0.382 \\
\hline Dependent & 0.516 & 0.552 & 0.519 & 0.928 & 0.386 \\
\hline Cumulative Hours Earned Prior to Entry & 11.34 & 11.505 & 11.15 & 0.795 & 0.660 \\
\hline Family Income & $\$ 22,576$ & $\$ 22,906$ & $\$ 20,756$ & 0.111 & 0.098 \\
\hline Between $0 \%$ and $50 \%$ of FPL & 0.228 & 0.264 & 0.262 & 0.244 & 0.946 \\
\hline Between $50 \%$ and $100 \%$ of FPL & 0.291 & 0.241 & 0.294 & 0.919 & 0.112 \\
\hline Between $100 \%$ and $150 \%$ of FPL & 0.216 & 0.221 & 0.198 & 0.511 & 0.459 \\
\hline Between $150 \%$ and $200 \%$ of FPL & 0.158 & 0.167 & 0.15 & 0.751 & 0.537 \\
\hline Above $200 \%$ of FPL & 0.107 & 0.107 & 0.096 & 0.581 & 0.615 \\
\hline Estimated Family Contribution (FAFSA) & $\$ 768$ & $\$ 761$ & $\$ 650$ & 0.242 & 0.292 \\
\hline Age $<20$ & 0.449 & 0.421 & 0.405 & 0.197 & 0.666 \\
\hline Age $20-25$ & 0.256 & 0.274 & 0.301 & 0.140 & 0.438 \\
\hline Age 26+ & 0.295 & 0.304 & 0.294 & 0.961 & 0.760 \\
\hline Black & 0.184 & 0.241 & 0.216 & 0.229 & 0.437 \\
\hline White & 0.405 & 0.418 & 0.408 & 0.926 & 0.780 \\
\hline Asian & 0.027 & 0.037 & 0.035 & 0.522 & 0.469 \\
\hline Other Race & 0.377 & 0.304 & 0.349 & 0.387 & 0.211 \\
\hline Hispanic & 0.477 & 0.438 & 0.460 & 0.624 & 0.556 \\
\hline Declared Intention to Earn Associate's Degree & 0.677 & 0.679 & 0.690 & 0.690 & 0.746 \\
\hline $\mathrm{N}$ & 430 & 299 & 439 & & \\
\hline
\end{tabular}


Table 5

The Effect of STC on Outcomes after Six Semesters for Main Sample and by Gender

\begin{tabular}{|c|c|c|c|c|c|c|}
\hline \multirow[b]{3}{*}{ Outcomes } & \multicolumn{2}{|c|}{ Full Sample } & \multicolumn{2}{|c|}{ Female Sample } & \multicolumn{2}{|c|}{ Male Sample } \\
\hline & ITT & TOT & IT'T & TOT & ITT & TOT \\
\hline & (1) & (2) & (3) & (4) & (5) & (6) \\
\hline \multirow{3}{*}{ Enrolled in College } & $0.056^{*}$ & $0.251^{*}$ & $0.084^{* *}$ & $0.358^{* *}$ & -0.003 & -0.014 \\
\hline & $(0.033)$ & $(0.152)$ & $(0.041)$ & $(0.178)$ & $(0.058)$ & $(0.293)$ \\
\hline & {$[0.440]$} & $\{0.238\}$ & {$[0.425]$} & $\{0.134\}$ & {$[0.471]$} & $\{0.498\}$ \\
\hline \multirow{3}{*}{ Total Credits Earned } & 1.764 & 7.717 & $2.846^{*}$ & 11.793* & -0.307 & -1.526 \\
\hline & $(1.314)$ & $(5.697)$ & $(1.682)$ & (6.931) & $(2.117)$ & $(10.361)$ \\
\hline & [26.829] & $\{24.171\}$ & {$[26.414]$} & $\{20.269\}$ & 27.725 & $\{33.083\}$ \\
\hline \multirow{3}{*}{ Cumulative GPA } & 0.026 & 0.116 & 0.046 & 0.195 & -0.005 & -0.025 \\
\hline & $(0.067)$ & $(0.295)$ & $(0.084)$ & $(0.352)$ & $(0.112)$ & $(0.552)$ \\
\hline & [2.495] & $\{0.189\}$ & [2.490] & $\{0.117\}$ & {$[2.504]$} & $\{0.426\}$ \\
\hline \multirow{3}{*}{ Earned any Degree } & 0.037 & 0.165 & $0.065^{*}$ & $0.278^{*}$ & -0.009 & -0.046 \\
\hline & $(0.026)$ & $(0.119)$ & $(0.034)$ & $(0.146)$ & $(0.042)$ & $(0.212)$ \\
\hline & [0.182] & $\{0.058\}$ & {$[0.187]$} & $\{0.000\}$ & {$[0.171]$} & $\{0.207\}$ \\
\hline \multirow{3}{*}{$\begin{array}{l}\text { Earned an Associate's } \\
\text { Degree }\end{array}$} & 0.036 & 0.162 & $0.074 * *$ & $0.315^{* *}$ & -0.025 & -0.129 \\
\hline & $(0.025)$ & $(0.115)$ & $(0.033)$ & $(0.141)$ & $(0.040)$ & $(0.205)$ \\
\hline & [0.159] & $\{0.029\}$ & [0.157] & $\{0.000\}$ & {$[0.164]$} & $\{0.258\}$ \\
\hline$\Lambda$ & 869 & 869 & 569 & 569 & 300 & 300 \\
\hline \multicolumn{7}{|c|}{$\begin{array}{l}\text { Notes: The Main Sample includes students assigned to the full STC treatment and those assigned to the control group. ITT } \\
\text { estimates ( } \beta_{1} \text { from equation } 1 \text { ) are from OLS regressions of the outcomes listed in each row on assignment to treatment age, age } \\
\text { squared, income, income squared, an indicator for female, and a set of race dummies. TOT estimates ( } \gamma_{1} \text { from equation } 2 \text { ) are } \\
\text { from } 2 \text { SLS regressions using assignment to treatment as an instrument for program participation. Take up }=1 \text { if client completes } \\
\text { an intake form. } 20 \text { observations are lost when analyzing cumulative GPA ( } 11 \text { females, } 9 \text { males) due to missing data. In instances } \\
\text { in which the Control Complier Mean (CCM) is negative, it is reported as zero--see Section V of the text for more details. } \\
\text { Statistics reported under point estimate: (Standard error) [Mean outcome in control group] \{CCM\}. *Significant at the } 10 \% \% \\
\text { level, **significant at the } 5 \% \text { level. }\end{array}$} \\
\hline
\end{tabular}


Table 6a

The Effect of STC on Outcomes after Six Semesters by Subsamples

\begin{tabular}{|c|c|c|c|c|c|c|c|c|}
\hline \multirow[b]{4}{*}{ Outcomes } & \multicolumn{4}{|c|}{ Income } & \multicolumn{4}{|c|}{ Race / Ethnicity } \\
\hline & \multicolumn{2}{|c|}{$\leq$ Median Income } & \multicolumn{2}{|c|}{$>$ Median Income } & \multicolumn{2}{|c|}{ White, Non-Hispanic } & \multicolumn{2}{|c|}{ Non-White } \\
\hline & $\overline{\text { ITT }}$ & TOT & ITT & TOT & ITT & TOT & ITT & TOT \\
\hline & (1) & (2) & (3) & (4) & (5) & (6) & (7) & (8) \\
\hline \multirow{3}{*}{ Enrolled in College } & 0.024 & 0.091 & $0.083^{*}$ & $0.441^{*}$ & 0.005 & 0.023 & $0.069^{*}$ & $0.318^{*}$ \\
\hline & $(0.047)$ & (0.178) & $(0.048)$ & $(0.259)$ & $(0.066)$ & $(0.284)$ & $(0.039)$ & (0.181) \\
\hline & {$[0.413]$} & $\{0.371\}$ & [0.469] & $\{0.083\}$ & [0.424] & $\{0.533\}$ & {$[0.455]$} & $\{0.145\}$ \\
\hline \multirow{3}{*}{ Total Credits Earned } & 0.459 & 1.720 & 2.817 & 14.203 & 2.403 & 9.965 & 1.615 & 7.233 \\
\hline & $(1.831)$ & $(6.754)$ & $(1.885)$ & $(9.439)$ & (2.604) & $(10.441)$ & $(1.520)$ & $(6.760)$ \\
\hline & [23.785] & $\{26.281\}$ & [30.214] & $\{22.544\}$ & [28.336] & $\{38.414\}$ & {$[26.270]$} & $\{29.091\}$ \\
\hline \multirow{3}{*}{ Cumulative GPA } & 0.009 & 0.033 & 0.031 & 0.166 & -0.039 & -0.168 & 0.053 & 0.238 \\
\hline & $(0.101)$ & $(0.374)$ & (0.088) & $(0.461)$ & $(0.125)$ & $(0.528)$ & $(0.079)$ & $(0.356)$ \\
\hline & {$[2.354]$} & $\{0.105\}$ & [2.647] & $\{0.341\}$ & [2.803] & $\{0.335\}$ & [2.391] & $\{0.140\}$ \\
\hline \multirow{3}{*}{ Earned any Degree } & 0.024 & 0.092 & 0.050 & 0.267 & 0.035 & 0.155 & 0.041 & 0.189 \\
\hline & $(0.036)$ & (0.135) & (0.039) & $(0.210)$ & $(0.051)$ & $(0.224)$ & (0.031) & $(0.142)$ \\
\hline & {$[0.161]$} & $\{0.100\}$ & [0.206] & $\{0.000\}$ & [0.203] & $\{0.104\}$ & {$[0.176]$} & $\{0.020\}$ \\
\hline \multirow{3}{*}{$\begin{array}{l}\text { Earned an Associate's } \\
\text { Degree }\end{array}$} & 0.029 & 0.109 & 0.045 & 0.240 & 0.065 & 0.289 & 0.028 & 0.127 \\
\hline & $(0.034)$ & (0.128) & (0.038) & $(0.204)$ & $(0.048)$ & $(0.217)$ & $(0.030)$ & (0.136) \\
\hline & {$[0.135]$} & $\{0.045\}$ & [0.187] & $\{0.000\}$ & [0.153] & $\{0.000\}$ & [0.157] & $\{0.067\}$ \\
\hline$N$ & 435 & 435 & 434 & 434 & 237 & 237 & 632 & 632 \\
\hline
\end{tabular}
Statistics reported under point estimate: (Standard error) [Mean outcome in control group] $\{C C M\}$. *Significant at the $10 \%$ level, **significant at the $5 \%$ level. See notes to Table 5 for more details. 
Table 6b

The Effect of STC on Outcomes after Six Semesters by Subsamples

\begin{tabular}{|c|c|c|c|c|c|c|c|c|c|c|}
\hline \multirow[b]{3}{*}{ Outcomes } & \multicolumn{4}{|c|}{ Initial Credit Hours } & \multicolumn{6}{|c|}{ Outcome Propensity } \\
\hline & \multicolumn{2}{|c|}{$>$ Median Hours } & \multicolumn{2}{|c|}{$\leq$ Median Hours } & \multicolumn{2}{|c|}{ Lower Third } & \multicolumn{2}{|c|}{ Middle Third } & \multicolumn{2}{|c|}{ Upper Third } \\
\hline & $\begin{array}{l}\text { IT'T } \\
\text { (1) }\end{array}$ & $\begin{array}{l}\text { TOT } \\
(2)\end{array}$ & $\begin{array}{l}\text { ITT } \\
\text { (3) }\end{array}$ & $\begin{array}{l}\text { TOT } \\
(4)\end{array}$ & $\begin{array}{l}\text { ITT } \\
(5)\end{array}$ & $\begin{array}{l}\text { TOT } \\
(6)\end{array}$ & $\begin{array}{l}\text { ITT } \\
(7)\end{array}$ & $\begin{array}{l}\text { TOT } \\
(8)\end{array}$ & $\begin{array}{c}\text { ITT } \\
(9)\end{array}$ & $\begin{array}{l}\text { TOT } \\
(10)\end{array}$ \\
\hline \multirow{3}{*}{ Enrolled in College } & 0.068 & 0.310 & 0.051 & 0.228 & 0.008 & 0.034 & 0.027 & 0.134 & $0.118^{* *}$ & $0.657 * *$ \\
\hline & $(0.048)$ & $(0.217)$ & $(0.047)$ & $(0.211)$ & $(0.054)$ & $(0.210)$ & $(0.049)$ & $(0.233)$ & $(0.053)$ & $(0.299)$ \\
\hline & {$[0.478]$} & $\{0.222\}$ & [0.399] & $\{0.219\}$ & {$[0.411]$} & $\{0.320\}$ & {$[0.464]$} & $\{0.417\}$ & {$[0.448]$} & $\{0.000\}$ \\
\hline \multirow{2}{*}{ Total Credits Earned } & $\begin{array}{c}0.886 \\
(1751)\end{array}$ & $\begin{array}{c}3.904 \\
(7.601)\end{array}$ & $\begin{array}{c}2.604 \\
(1.973)\end{array}$ & $\begin{array}{l}11.304 \\
(8.394)\end{array}$ & $\begin{array}{c}0.404 \\
(2.245)\end{array}$ & $\begin{array}{r}1.603 \\
(9447)\end{array}$ & $\begin{array}{l}-0.246 \\
(1.759)\end{array}$ & $\begin{array}{l}-1.106 \\
(7.617)\end{array}$ & $\begin{array}{l}4.066^{*} \\
(2.146)\end{array}$ & $\begin{array}{c}21.048^{*} \\
(11290)\end{array}$ \\
\hline & [27.373] & $\{26.223\}$ & [26.279] & $\{22.269\}$ & [21.764] & $\{23.975\}$ & [28.741] & $\{33.689\}$ & [31.164] & $\{17.996\}$ \\
\hline \multirow{3}{*}{ Cumulative GPA } & 0.012 & 0.055 & 0.043 & 0.194 & -0.053 & -0.237 & 0.061 & 0.308 & 0.050 & 0.214 \\
\hline & $(0.043)$ & $(0.192)$ & $(0.042)$ & (0.188) & $(0.131)$ & $(0.663)$ & $(0.088)$ & $(0.449)$ & $(0.103)$ & $(0.457)$ \\
\hline & {$[2.704]$} & $\{0.243\}$ & [2.258] & $\{0.125\}$ & {$[2.177]$} & $\{2.702\}$ & [2.581] & $\{2.288\}$ & [2.757] & $\{2.614\}$ \\
\hline \multirow{3}{*}{ Earned any Degree } & 0.010 & 0.047 & $0.056^{*}$ & 0.251 & 0.008 & 0.037 & -0.002 & -0.016 & $0.094 *$ & $0.419 *$ \\
\hline & $(0.040)$ & $(0.182)$ & $(0.034)$ & $(0.153)$ & $(0.035)$ & $(0.162)$ & $(0.042)$ & $(0.209)$ & $(0.054)$ & $(0.255)$ \\
\hline & [0.239] & $\{0.230\}$ & [0.122] & $\{0.000\}$ & {$[0.096]$} & $\{0.067\}$ & [0.205] & $\{0.218\}$ & {$[0.251]$} & $\{0.000\}$ \\
\hline \multirow{3}{*}{$\begin{array}{l}\text { Earned an Associate's } \\
\text { Degree }\end{array}$} & 0.018 & 0.080 & 0.047 & 0.214 & 0.012 & 0.053 & 0.023 & 0.098 & 0.068 & 0.334 \\
\hline & $(0.039)$ & $(0.176)$ & $(0.032)$ & (0.144) & $(0.030)$ & (0.141) & (0.035) & (0.163) & (0.049) & (0.163) \\
\hline & {$[0.208]$} & $\{0.154\}$ & [0.108] & $\{0.000\}$ & [0.095] & $\{0.031\}$ & [0.163] & $\{0.089\}$ & [0.223] & $\{0.000\}$ \\
\hline
\end{tabular}

\begin{tabular}{llllllllll}
$\Lambda$ & 444 & 444 & 425 & 425 & 290 & 290 & 289 & 289 & 290 \\
\hline
\end{tabular}

Notes: Results are for subgroups of the Main Sample that includes students assigned to the full STC treatment and those assigned to the control group. Degree propensity is the predicted probability of earning a degree after six semesters, which is estimated on the control group using a probit model that includes as controls observable characteristics at baseline. See Section V of the text for more details. Statistics reported under point estimate: (Standard error) [Mean outcome in control group] \{CCM\}. *Significant at the 10\% level, **significant at the $5 \%$ level. See notes to Table 5 for more details. 
Table 7

The Effect of EFA on Outcomes after Six Semesters for the Full EFA Sample and by Gender

\begin{tabular}{|c|c|c|c|c|c|c|}
\hline \multirow[b]{3}{*}{ Outcomes } & \multicolumn{2}{|c|}{ Full Sample } & \multicolumn{2}{|c|}{ Female Sample } & \multicolumn{2}{|c|}{ Male Sample } \\
\hline & ITT & TOT & ITT & TOT & IT'T & TOT \\
\hline & (1) & $(2)$ & (3) & (4) & (5) & $(6)$ \\
\hline \multirow{3}{*}{ Enrolled in College } & 0.015 & 0.036 & 0.010 & 0.024 & 0.027 & 0.073 \\
\hline & $(0.037)$ & $(0.088)$ & $(0.046)$ & $(0.104)$ & $(0.065)$ & $(0.168)$ \\
\hline & {$[0.440]$} & $\{0.456\}$ & {$[0.425]$} & $\{0.505\}$ & {$[0.471]$} & $\{0.342\}$ \\
\hline \multirow{3}{*}{ Total Credits Earned } & -0.443 & -1.080 & -1.068 & -2.508 & 0.706 & 1.883 \\
\hline & $(1.448)$ & $(3.509)$ & $(1.761)$ & $(4.110)$ & $(2.615)$ & $(6.803)$ \\
\hline & [26.829] & $\{29.756\}$ & [26.414] & $\{31.548\}$ & [27.725] & $\{26.057\}$ \\
\hline \multirow{3}{*}{ Cumulative GPA } & -0.108 & -0.259 & -0.089 & -0.206 & -0.131 & -0.348 \\
\hline & $(0.079)$ & $(0.190)$ & $(0.097)$ & $(0.223)$ & $(0.139)$ & $(0.363)$ \\
\hline & [2.495] & $\{2.784\}$ & {$[2.490]$} & $\{2.825\}$ & {$[2.504]$} & $\{2.678\}$ \\
\hline \multirow{3}{*}{ Earned any Degree } & -0.014 & -0.034 & -0.032 & -0.073 & 0.017 & 0.045 \\
\hline & $(0.029)$ & $(0.068)$ & $(0.035)$ & $(0.080)$ & $(0.050)$ & $(0.130)$ \\
\hline & 0.182 & $\{0.248\}$ & {$[0.187]$} & $\{0.285\}$ & {$[0.171]$} & $\{0.175\}$ \\
\hline \multirow{3}{*}{$\begin{array}{l}\text { Earned an Associate's } \\
\text { Degree }\end{array}$} & -0.012 & -0.028 & -0.014 & -0.032 & -0.007 & -0.018 \\
\hline & $(0.027)$ & $(0.065)$ & $(0.033)$ & $(0.076)$ & $(0.048)$ & $(0.126)$ \\
\hline & [0.159] & $\{0.218\}$ & {$[0.157]$} & $\{0.208\}$ & [0.164] & $\{0.238\}$ \\
\hline $\mathrm{N}$ & 738 & 738 & 491 & 491 & 247 & 247 \\
\hline
\end{tabular}

Notes: Results are for the EFA Sample $(\mathrm{N}=772)$ that includes students assigned to the EFA only treatment and those assigned to the control group. Statistics reported under point estimate: (Standard error) [Mean outcome in control group] $\{C C M\}$. *Significant at the $10 \%$ level, **significant at the $5 \%$ level. See notes to Table 5 for more details. 
Table 8

The Effect of STC on Outcomes after Two Semesters for Main Sample and by Gender

\begin{tabular}{|c|c|c|c|c|c|c|}
\hline \multirow{3}{*}{ Outcomes } & \multicolumn{2}{|c|}{ Full Sample } & \multicolumn{2}{|c|}{ Female Sample } & \multicolumn{2}{|c|}{ Male Sample } \\
\hline & ITT & TOT & ITT & TOT & ITT & TOT \\
\hline & $\frac{(1)}{0 \Omega 64 * *}$ & $\frac{(2)}{0280 * *}$ & $\frac{(2)}{0075 * *}$ & $\frac{(4)}{0310 * *}$ & $\frac{0040}{(3)}$ & $\frac{0206}{206}$ \\
\hline \multirow{3}{*}{$\begin{array}{l}\text { Enrolled in Classes at } \\
\text { TCC }\end{array}$} & $0.004^{17 \pi}$ & $0 . \angle 89{ }^{2}$ & $0.075^{2}$ & $0.319+4$ & 0.040 & 0.200 \\
\hline & $(0.027)$ & $(0.121)$ & (0.034) & (0.143) & (0.045) & $(0.225)$ \\
\hline & {$[0.759]$} & $\{0.544\}$ & {$[0.749]$} & $\{0.586\}$ & {$[0.779]$} & $\{0.625\}$ \\
\hline \multirow{3}{*}{ Enrolled in College } & 0.016 & 0.072 & 0.036 & 0.153 & -0.027 & -0.140 \\
\hline & $(0.026)$ & $(0.117)$ & $(0.033)$ & $(0.140)$ & $(0.042)$ & $(0.218)$ \\
\hline & {$[0.797]$} & $\{0.811\}$ & {$[0.783]$} & $\{0.720\}$ & [0.829] & $\{1.043\}$ \\
\hline \multirow{3}{*}{ Total Credits Earned } & $1.064^{*}$ & $4.749^{*}$ & $1.238^{*}$ & $5.200^{*}$ & 0.781 & 4.028 \\
\hline & $(0.560)$ & $(2.486)$ & $(0.698)$ & $(2.912)$ & $(0.950)$ & $(4.807)$ \\
\hline & [13.897] & $\{11.832\}$ & [13.772] & $\{11.467\}$ & [14.168] & $\{12.372\}$ \\
\hline \multirow{3}{*}{ Cumulative GPA } & 0.055 & 0.243 & 0.063 & 0.266 & 0.054 & 0.271 \\
\hline & $(0.070)$ & $(0.309)$ & $(0.088)$ & $(0.369)$ & $(0.118)$ & $(0.577)$ \\
\hline & {$[2.468]$} & $\{2.442\}$ & [2.469] & $\{2.365\}$ & [2.465] & $\{2.522\}$ \\
\hline \multirow{3}{*}{ Earned any Degree } & 0.012 & 0.054 & 0.011 & 0.011 & 0.012 & 0.064 \\
\hline & $(0.008)$ & $(0.035)$ & $(0.010)$ & $(0.010)$ & $(0.013)$ & $(0.069)$ \\
\hline & {$[0.007]$} & $\{0.000\}$ & {$[0.007]$} & $\{0.005\}$ & {$[0.007]$} & $\{0.000\}$ \\
\hline \multirow{3}{*}{$\begin{array}{l}\text { Earned an Associate's } \\
\text { Degree }\end{array}$} & 0.008 & 0.035 & 0.009 & 0.038 & 0.006 & 0.029 \\
\hline & $(0.006)$ & $(0.029)$ & $(0.008)$ & $(0.033)$ & $(0.012)$ & $(0.059)$ \\
\hline & {$[0.005]$} & $\{0.000\}$ & {$[0.003]$} & $\{0.000\}$ & {$[0.007]$} & $\{0.000\}$ \\
\hline $\mathrm{N}$ & 869 & 869 & 569 & 569 & 300 & 300 \\
\hline
\end{tabular}


Table 9

The Effect of STC on Outcomes after Four Semesters for Main Sample and by Gender

\begin{tabular}{|c|c|c|c|c|c|c|}
\hline \multirow[b]{3}{*}{ Outcomes } & \multicolumn{2}{|c|}{ Full Sample } & \multicolumn{2}{|c|}{ Female Sample } & \multicolumn{2}{|c|}{ Male Sample } \\
\hline & ITT & TOT & ITT & TOT & ITT & TOT \\
\hline & (1) & (2) & (3) & (4) & (5) & (6) \\
\hline \multirow{3}{*}{$\begin{array}{l}\text { Enrolled in Classes at } \\
\text { TCC }\end{array}$} & -0.008 & -0.037 & -0.008 & -0.035 & 0.009 & 0.047 \\
\hline & $(0.034)$ & $(0.152)$ & $(0.042)$ & $(0.177)$ & $(0.057)$ & $(0.290)$ \\
\hline & {$[0.456]$} & $\{0.473\}$ & {$[0.468]$} & $\{0.463\}$ & {$[0.429]$} & $\{0.405\}$ \\
\hline \multirow{3}{*}{ Enrolled in College } & -0.017 & -0.077 & -0.005 & -0.021 & -0.030 & -0.155 \\
\hline & $(0.032)$ & $(0.145)$ & $(0.041)$ & $(0.172)$ & $(0.054)$ & $(0.276)$ \\
\hline & {$[0.604]$} & $\{0.609\}$ & {$[0.582]$} & $\{0.528\}$ & {$[0.650]$} & $\{0.736\}$ \\
\hline \multirow{3}{*}{ Total Credits Earned } & 1.097 & 4.914 & 1.895 & 8.016 & -0.155 & -0.794 \\
\hline & (1.031) & $(4.579)$ & $(1.309)$ & $(5.506)$ & $(1.670)$ & $(8.380)$ \\
\hline & [23.138] & $\{21.449\}$ & {$[22.756]$} & $\{18.428\}$ & [23.962] & $\{26.996\}$ \\
\hline \multirow{3}{*}{ Cumulative GPA } & 0.022 & 0.097 & 0.038 & 0.159 & 0.012 & 0.061 \\
\hline & $(0.068)$ & $(0.299)$ & $(0.087)$ & $(0.360)$ & $(0.114)$ & $(0.558)$ \\
\hline & {$[2.476]$} & $\{2.544\}$ & [2.466] & $\{2.460\}$ & [2.463] & $\{2.661\}$ \\
\hline \multirow{3}{*}{ Earned any Degree } & -0.013 & -0.061 & -0.012 & -0.050 & -0.010 & -0.053 \\
\hline & $(0.020)$ & (0.087) & $(0.026)$ & (0.108) & $(0.029)$ & $(0.146)$ \\
\hline & [0.100] & $\{0.114\}$ & [0.110] & $\{0.129\}$ & {$[0.079]$} & $\{0.053\}$ \\
\hline \multirow{3}{*}{$\begin{array}{l}\text { Earned an Associate's } \\
\text { Degree }\end{array}$} & -0.004 & -0.020 & 0.002 & 0.008 & -0.007 & -0.037 \\
\hline & (0.019) & (0.084) & (0.025) & (0.104) & $(0.027)$ & (0.139) \\
\hline & {$[0.087]$} & $\{0.063\}$ & {$[0.094]$} & $\{0.055\}$ & {$[0.071]$} & $\{0.037\}$ \\
\hline $\mathrm{N}$ & 869 & 869 & 569 & 569 & 300 & 300 \\
\hline
\end{tabular}


Figure 1

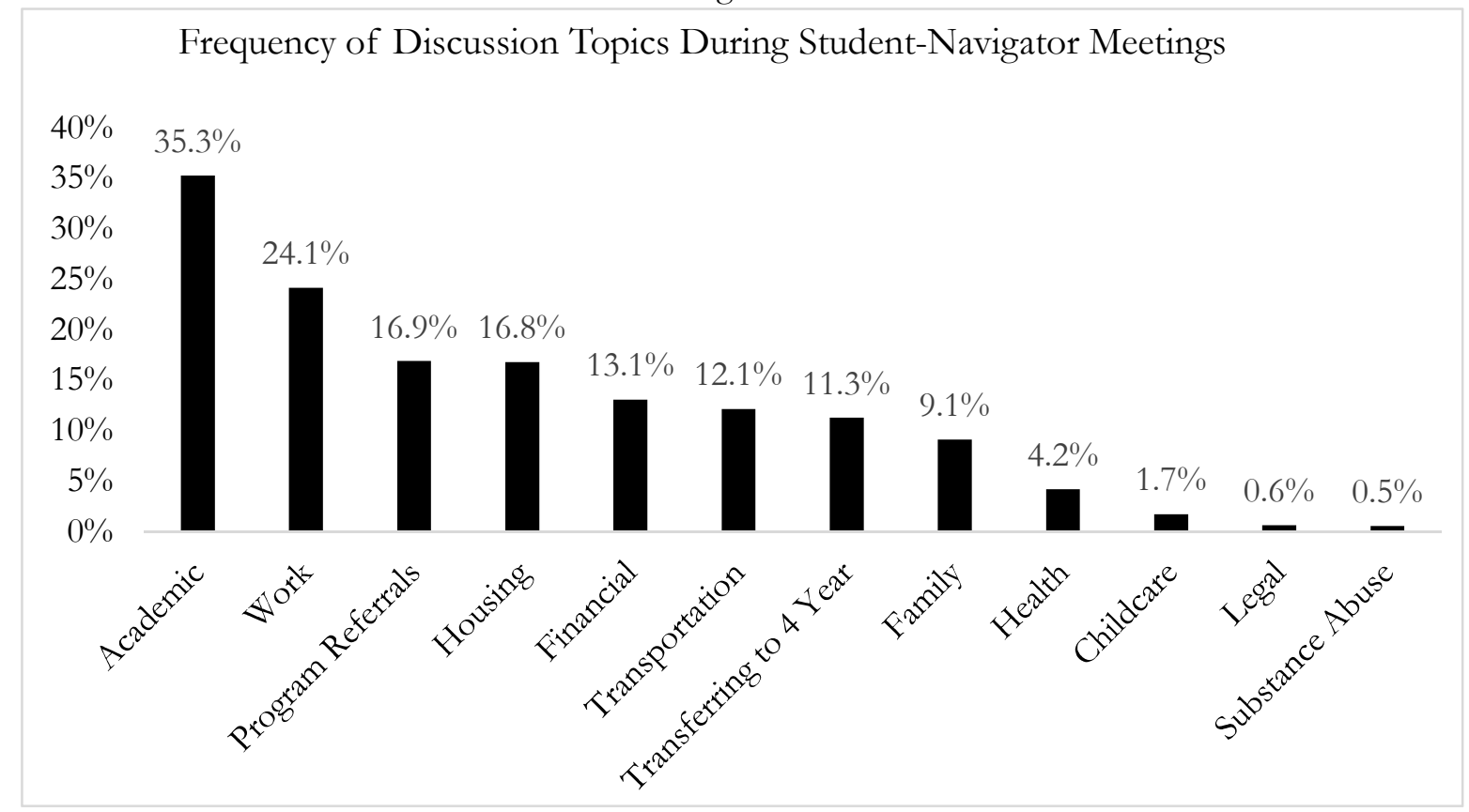

Notes: Topics such as academic, work, and health are an aggregate of several, more specific categories. Mass emails and administrative records have been excluded (meaningful interactions only, $\mathrm{N}=2,382$ ). All data are for the Main Sample. Topic Discussion data is only available for meetings that occurred between 8/23/13 - 7/14/15. 
Figure 2

Breakdown of EFA for STC Participants by Payment Type

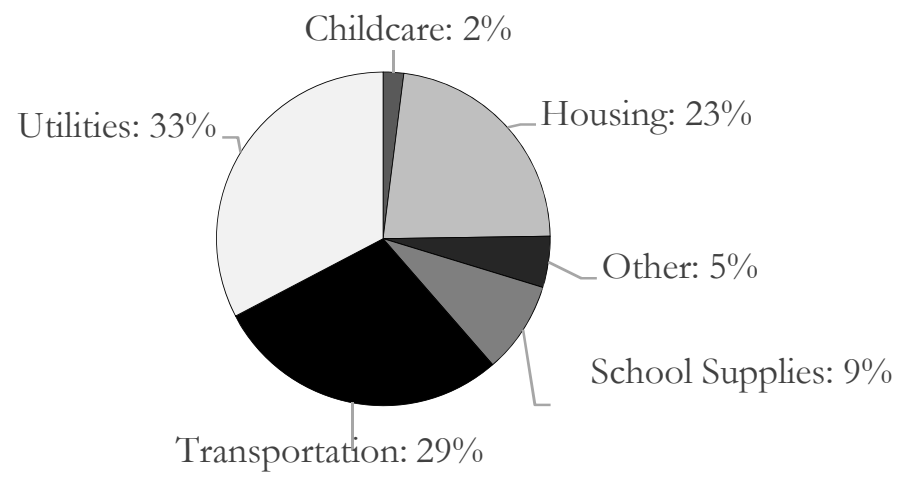

Notes: Data are from CCFW case notes. Sample includes all EFA payments to STC participants $(\mathrm{N}=94)$. 
Figure 3

Consort Diagram for RCT Research Design

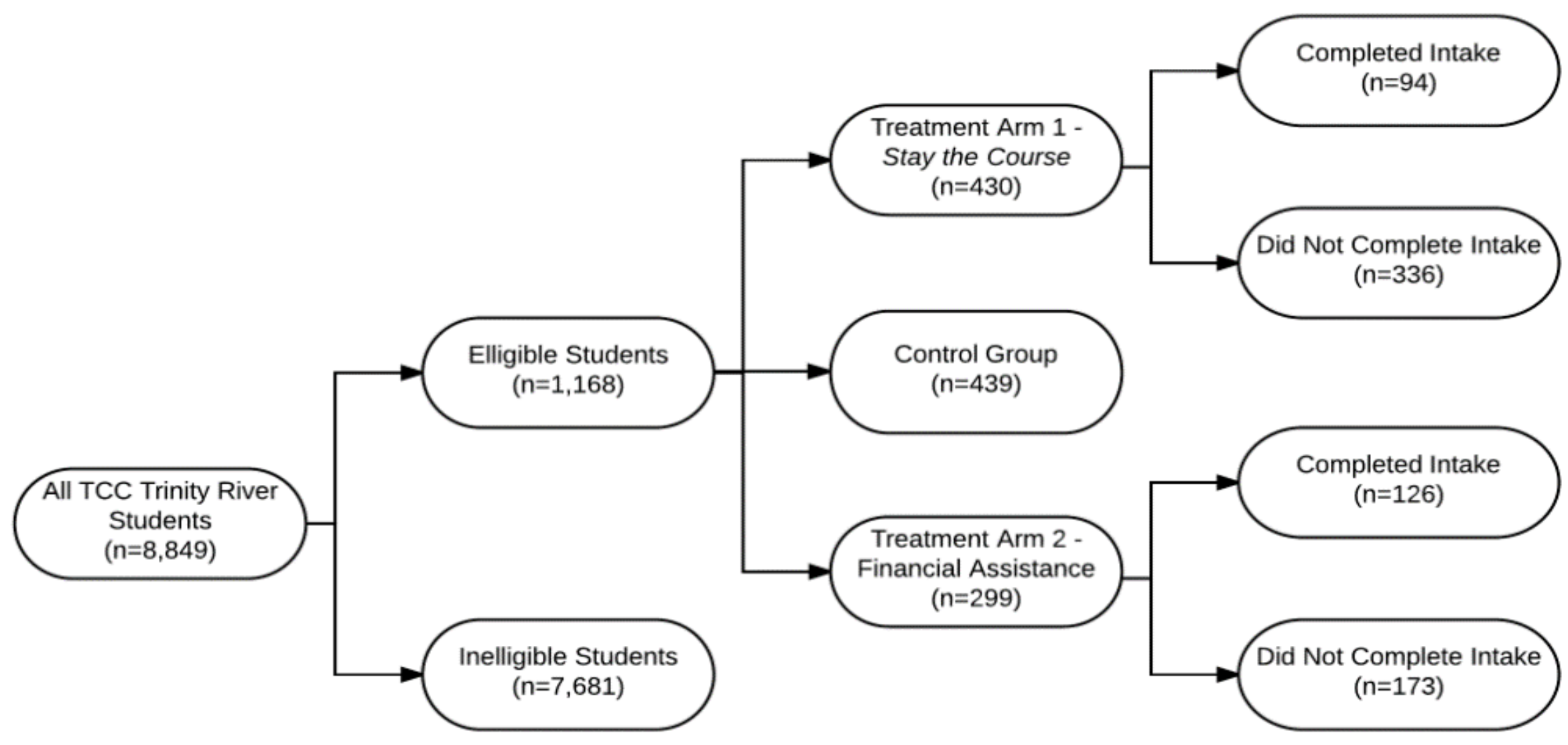


Appendix Table 1

Baseline Descriptive Statistics by Compliance Status

\begin{tabular}{|c|c|c|c|c|c|c|}
\hline \multirow[b]{3}{*}{ Varaible } & \multicolumn{3}{|c|}{ STC Treatment Group } & \multicolumn{3}{|c|}{ EFA Treatment Group } \\
\hline & Compliers & $\begin{array}{c}\text { Non- } \\
\text { compliers }\end{array}$ & $\begin{array}{c}\text { P-value on } \\
\text { Test that } \\
\text { Means are } \\
\text { the same } \\
\text { Across } \\
\text { Groups }\end{array}$ & Compliers & $\begin{array}{c}\text { Non- } \\
\text { compliers }\end{array}$ & $\begin{array}{c}\text { P-value on } \\
\text { Test that } \\
\text { Means are } \\
\text { the same } \\
\text { Across } \\
\text { Groups }\end{array}$ \\
\hline & $(1)$ & $(2)$ & (3) & $(4)$ & $(5)$ & $(6)$ \\
\hline Age at Entry & 25.78 & 23.62 & 0.017 & 26.751 & 23.491 & 0.001 \\
\hline Female & 0.67 & 0.616 & 0.338 & 0.675 & 0.618 & 0.319 \\
\hline TSI's Remaining at Entry & 0.574 & 0.527 & 0.571 & 0.587 & 0.480 & 0.197 \\
\hline Dependent & 0.457 & 0.533 & 0.197 & 0.484 & 0.601 & 0.045 \\
\hline Cumulative Hours Earned Prior to Entry & 10.69 & 11.52 & 0.52 & 11.817 & 11.277 & 0.676 \\
\hline Family Income & $\$ 20,121$ & $\$ 23,263$ & 0.116 & $\$ 23,812$ & $\$ 22,246$ & 0.467 \\
\hline Between $0 \%$ and $50 \%$ of FPL & 0.287 & 0.211 & 0.121 & 0.262 & 0.266 & 0.939 \\
\hline Between $50 \%$ and $100 \%$ of FPL & 0.309 & 0.286 & 0.668 & 0.230 & 0.249 & 0.714 \\
\hline Between $100 \%$ and $150 \%$ of FPL & 0.181 & 0.226 & 0.346 & 0.214 & 0.225 & 0.819 \\
\hline Between $150 \%$ and $200 \%$ of FPL & 0.138 & 0.164 & 0.552 & 0.175 & 0.162 & 0.771 \\
\hline Above $200 \%$ of FPL & 0.085 & 0.113 & 0.439 & 0.119 & 0.098 & 0.568 \\
\hline Estimated Family Contribution (FAFSA) & $\$ 730$ & $\$ 779$ & 0.793 & $\$ 801$ & $\$ 732$ & 0.677 \\
\hline Under 20 Years Old & 0.372 & 0.47 & 0.092 & 0.365 & 0.462 & 0.093 \\
\hline Between 20 and 25 Years Old & 0.266 & 0.253 & 0.799 & 0.262 & 0.283 & 0.684 \\
\hline Above 25 Years Old & 0.362 & 0.277 & 0.111 & 0.373 & 0.254 & 0.028 \\
\hline Black & 0.181 & 0.185 & 0.935 & 0.262 & 0.225 & 0.468 \\
\hline White & 0.415 & 0.402 & 0.819 & 0.421 & 0.416 & 0.939 \\
\hline Asian & 0.036 & 0.032 & 0.86 & 0.040 & 0.035 & 0.821 \\
\hline Other Race & 0.372 & 0.378 & 0.921 & 0.278 & 0.324 & 0.396 \\
\hline Hispanic & 0.436 & 0.488 & 0.374 & 0.413 & 0.457 & 0.451 \\
\hline Declared Intention to Earn Associate's Degree & 0.723 & 0.664 & 0.275 & 0.722 & 0.647 & 0.172 \\
\hline $\mathrm{N}$ & 94 & 336 & & 126 & 173 & \\
\hline
\end{tabular}

